\title{
A comparative appraisal of the resilience of marine social-ecological systems to mass mortalities of bivalves
}

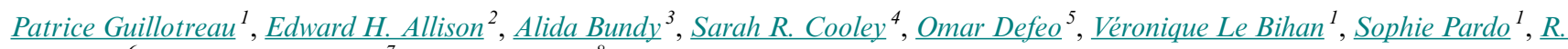 \\ Ian Perrv $^{6}$, George Santopietro ${ }^{7}$ and Tetsuo Seki ${ }^{8}$
}

\begin{abstract}
In many parts of the world, both wild and cultured populations of bivalves have been struck by mass mortality episodes because of climatic and anthropogenic stressors whose causes and consequences are not always clearly understood. Such outbreaks have resulted in a range of responses from the social (fishers or farmers) and governing systems. We analyzed six commercial bivalve industries affected by mass mortalities using I-ADApT, a decision support framework to assess the impacts and consequences of these perturbations on the natural, social, and governing systems, and the consequent responses of stakeholders to these events. We propose a multidimensional resilience framework to assess resilience along the natural, social, and governing axes and to compare adaptive responses and their likelihood of success. The social capital and governability of the local communities were key factors affecting the communities' resilience and adaptation to environmental changes, but the rapid degradation of natural ecosystems puts the bivalve industry under a growing threat. Bivalve mariculture and fishing industries are likely to experience increased frequency, severity, and prevalence of such mass mortality events if the resilience of the natural systems is not improved. An understanding of previous adaptation processes can inform strategies for building adaptive capacity to future events.
\end{abstract}

Key Words: I-ADApT; mass mortality; response appraisal; shellfish

\section{INTRODUCTION}

In the present Anthropocene era (Crutzen and Stoermer 2000), a key emerging concern is whether our social and governing systems are able to adapt to the new environmental conditions we are creating in the short and long terms, as well as locally and globally. How do they respond to stresses threatening environmental resources? Do their responses enhance or harm the resilience of the perturbed natural systems? A systems and resilience-based approach that considers the three systems together and the interactions between them is needed, rather than considering the systems individually or failing to consider the social and governing systems' actions entirely (Steffen et al. 2007, Folke at al. 2010).

Various terms are used in the literature to refer to what we call a "systems approach," including social-ecological systems (Berkes and Folke 1998, Folke et al. 2005, 2010, Berkes 2011, Perry et al. 2011), human-environment systems (Turner et al. 2003), and coupled human and natural systems approaches (Liu et al. 2007). Here, we recognize that the delineation between human and ecological systems is artificial and arbitrary (Berkes and Folke 1998) and that the relationship between humans and the environment is complex, bidirectional, and occurs at different but interrelated spatial and temporal scales.

The concept of resilience is helpful to describe the capacity of a social-ecological system to recover after a perturbation (Holling 1973, Walker and Salt 2006, Folke et al. 2010). This concept has to be understood in several dimensions (static and dynamic, ecological and social), which are not easy to disentangle, for example, in human-dominated systems such as shellfish farming. Resilience thinking also challenges conventional optimization and efficiency approaches applied to exploited ecological systems because the living world is changing and is configured by extreme events rather than average conditions (Walker and Salt 2006). Redundancies, often considered to be sources of inefficiency, can create resilience when a system faces external shocks and regime shifts (Biggs et al. 2012, 2015). We therefore hypothesize that social responses to ecological impacts are key factors of resilience and the degree to which bivalve systems can recover.

Here, we propose an assessment framework and develop a measure of resilience, focusing on mass mortalities of bivalves (MMB). These outputs contribute to the metrics of resilience and allow for international cross-case comparisons (Béné 2013), simplifying the complexity of concepts and processes at stake (Nemec et al. 2013, Quinlan et al. 2015), and identifying risks, opportunities, and alternate management strategies in marine systems (Resilience Alliance 2010). The multidimensional resilience framework (MRF) is able to capture, analyze, and assess responses within the natural, social, and governing systems. To test this framework, we use metrics based on responses to MMB gathered from six case studies of bivalve fisheries and farming systems using the "Assessment based on Description, Responses, and Appraisal for a Typology" (ADApT) approach developed by the Human Dimensions Working Group of the Integrated Marine Biogeochemistry and Ecosystem Research (IMBER) program (Bundy et al. 2016). By applying the MRF to local case studies of environmental change and societal adaptation, we demonstrate the value of this approach to facilitate learning from other case studies presenting similar natural and social characteristics. Our approach is also used to illustrate how societies can cope with or adapt to adverse events that may ultimately be derived from altered biogeochemical cycles and interactions with local environmental stressors.

${ }^{1}$ LEMNA, University of Nantes, France, ${ }^{2}$ School of Marine and Environmental Affairs, University of Washington, USA, ${ }^{3}$ Fisheries and Oceans Canada, Bedford Institute of Oceanography, Halifax, Canada, ${ }^{4}$ Ocean Conservancy, Washington, D.C., USA, ${ }^{5}$ UNDECIMAR, Facultad de Ciencias, Universidad de la Republica, Montevideo, Uruguay, ${ }_{6}^{6}$ Fisheries and Oceans Canada, Pacific Biological Station, Nanaimo, Canada, ${ }^{7}$ Economics Department, Radford University, USA, ${ }^{8}$ Japan Fisheries Science and Technology Association, Tokyo, Japan 


\section{REVIEW OF LITERATURE}

The (long) history of mass mortalities of bivalves

Oysters, mussels, and clams are economically valuable, constitute significant sources of nutrition, and are part of cultural identities. In 2013, 15.3 million tonnes of marine bivalves were produced around the world (of which $89 \%$ was from aquaculture) for a primary value (ex-farm or ex-vessel) of $\$ 17.6$ billion USD (FAO 2016). MMB events have been reported worldwide and have long been of particular concern, especially when the species supports a commercial fishery or plays a significant role in an ecosystem (Lafferty et al. 2004, Burdon et al. 2014). One of the first descriptions of an MMB outbreak dates to 1878 , with the observation of bivalve diseases (Lafferty et al. 2004). Mass (or abnormal) mortalities of bivalve populations are generally defined as a loss of $>30 \%$ of the stock (Soletchnik et al. 2007, EFSA 2010). An increasing number of MMB outbreaks throughout the world has been reported since the 1960s (Imaï et al. 1965, Harvell et al. 1999, Lafferty et al. 2004, Soletchnik et al. 2007). This increase can be explained as a result of research progress on identification of diseases, the intensification of bivalve aquaculture, or may reflect changes in environmental conditions in production areas caused by climate change and water pollution.

Various causes have been identified for MMB outbreaks, including: high sea temperatures and heat waves (Cheney et al. 2000, Ortega et al. 2012, 2016, Rodrigues et al. 2015); changes in salinity (Xiao et al. 2005), turbidity, and $\mathrm{pH}$; high primary production (Cheney et al. 2000, Mydlarz et al. 2006); eutrophic waters (Friedman and Hedrick 1991); invasive species as competitors or predators (Matsuyama 1999, McKindsey et al. 2007); pathogens (Elston et al. 1987); and density-dependent factors (Brazeiro and Defeo 1999, Xiao et al. 2005).

While a great deal of research has been devoted to the discovery of scientific causes behind $\mathrm{MMB}$, the socioeconomic consequences of $\mathrm{MMB}$ events and the responses adopted by managers and growers or harvesters to cope with them have been described less frequently in the literature. Nevertheless, it is the study of these responses that is needed to guide efforts to minimize impacts and maximize recovery times. Have documented responses been successful at mitigating the outbreak or the effects of MMB on human communities, or not? What are the characteristics of successful responses? These are the questions that motivate our research.

\section{Societal responses to mass mortalities of bivalves issues}

MMB events have elicited a range of short-term and long-term responses among stakeholders and in governing and social systems, with dissimilar levels of success in restoring the system. These responses can be divided into two groups, technical and organizational, and they vary according to the production process, i.e., whether bivalves come from fisheries or farming systems. Technical measures primarily concern aquaculture systems, although operational management options (e.g., fishing gear selectivity) are also common for fisheries. Organizational measures can be applied to both wild-caught and farmed species. Fisheries and aquaculture must be envisaged as a continuum because enhancement programs may benefit both fishery systems, e.g., pollution reduction, and some farming systems that may also rely on wild-caught species (Anderson 2002).
Technical measures that have had some success include: (1) introduction of new or resistant species and varying the sources of spat to maintain the same level of economic activity (Grizel 1983, Grizel and Héral 1991, Ewart and Ford 1993, McKindsey et al. 2007, Padilla 2010, Castinel et al. 2015); (2) chemical or physical solutions such as water treatment, animal purification, immunostimulants, penicillin, active clay, hydrogen peroxide, and coagulants to prevent or limit disease (Di Salvo et al. 1978, Matsuyama 1999, Mydlarz et al. 2006); and (3) prevention measures such as monitoring and surveillance systems, quarantine and prevention of oyster movements to contain the disease, awareness and reporting by the industry, and risk assessment (Matsuyama 1999, Hine et al. 2001, Murray et al. 2012, Paul-Pont et al. 2014, Castinel et al. 2015). Organizational responses (e.g., state aid, mutual funds, diversification strategies, private insurance, inventories, and savings) occur at both individual and collective levels (Grizel 1983, Le Bihan et al. 2013, Lupo et al. 2014). These responses also take the form of changes in practices and management rules such as limiting effort, reducing bivalve density, going off the coast, changing the culture height in the water column, triage of dead oysters, and building cages against predation (Smith et al. 2000, Cassis et al. 2011, Pernet et al. 2011, Soletchnik et al. 2011).

These technical and organizational responses may also have potential negative and positive consequences in terms of "ecosystem engineering" (Padilla 2010). The introduction of new species such as Crassostrea gigas in many natural systems around the world has led to the introduction of pathogens or plankton attached to new imported species (Grizel and Héral 1991, McKindsey et al. 2007), but this has also created new substrates or three-dimensional habitats for other species, altered local hydrodynamics, and even changed the thermal environment through the radiant energy absorbed by their white shells on dark rocks (Padilla 2010). This one example illustrates that when assessing how well responses have worked, the objectives and stakes for the broader natural, social, and governing systems should be considered, raising new questions about the system's resilience to the initial $\mathrm{MMB}$ event and the responses by the human social systems.

\section{METHODS}

\section{Definitions of resilience}

The concept of resilience is useful to describe the capacity of a marine system to recover after a perturbation. Its origins are in ecology, where it was first introduced by Holling (1973) and defined by Walker et al. (2004) to describe "the capacity of a system to absorb disturbance and reorganize while undergoing change so as to still retain essentially the same function, structure, identity and feedbacks." Pimm (1984) extended this concept to include "engineering resilience," a measure of the time it takes a system to return to "equilibrium" after disturbance. Resilience is now considered to include not only recovery but also resistance and reversibility (Palumbi et al. 2008). Resilience thinking has been extended beyond ecology and has been highly influential in systems approaches that integrate the social dimensions and interconnections between community well-being and ecosystems (Carpenter et al. 2001, Folke et al. 2002, Marshall et al. 2007). Folke et al. (2010) contend that that the concept of resilience should not be limited to ecosystem dynamics as traditionally 
understood. They argue rather for thinking of social-ecological resilience because "ecosystems and the social systems that use and depend upon them are inextricably linked" (Folke et al. 2010:2).

Here, we build upon operational definitions of resilience in a variety of domains (social, natural, and governing subsystems) to develop an MRF for MMB issues. Similar attempts have been undertaken in the past (Walker et al. 2004, Resilience Alliance 2010, Béné 2013, Nemec et al. 2013). Simplifying complex concepts without compromising the method's systemic and holistic approach remains an important challenge for resilience metrics (Walker and Salt 2006, Quinlan et al. 2015). Therefore, instead of reporting on every characteristic of resilience for both ecological and social systems, we assessed resilience through an equal weighting of the three (natural, social, and governing) systems rated along static and dynamic issues. Each of the six dimensions in our framework is characterized by a set of questions developed in the I-ADApT questionnaire and complemented by the scientific literature (Table $\mathrm{C}$ in Appendix 1).

\section{Natural resilience}

Natural or ecological resilience was assessed using two measures. The Holling resilience (H-resilience; Holling 1973) refers to the ability of an ecosystem to maintain its previous structure and function (i.e., the same biodiversity, trophic relationships, habitats, etc. before and after the shock). Systems were scored with a high $\mathrm{H}$-resilience if the ecosystem maintained its state after a shock of a given magnitude, medium if there was partial maintenance, and low if the shock resulted in an altered state. Pimm's engineering resilience (P-resilience; Pimm 1984) was scored high if the speed of recovery after a shock was days to weeks, medium if recovery took several months, and low if recovery took several years or decades or did not occur. We also considered whether the natural ( $\mathrm{H}$ - or $\mathrm{P}-)$ resilience is affected by the intensity of the shock because the speed of recovery relative to the shock itself also matters (Palumbi et al. 2008). Therefore, natural systems will be considered to be more resilient if their recovery is still possible after a severe perturbation.

\section{Socioeconomic resilience}

The communities involved in bivalve production systems are generally based on family-owned and small business units. From a social and economic point of view, resilience is defined as the ability of social systems to minimize welfare losses after a perturbation (Hallegate 2014). Socioeconomic resilience was described by two components analogous to $\mathrm{H}$ - and P-resilience (Rose 2004, 2007, Rose and Krausmann 2013): (1) Static socioeconomic resilience (S-resilience; Rose 2004) was defined as the ability of a system to maintain its functions (providing food, cultural value, employment, trade, profits, recreational use) when shocked, using the remaining resources as efficiently as possible during the course of recovery. S-resilience was considered high if the key indicators described above (e.g., output levels, employment, profits, cultural value) are fully preserved, medium if partially preserved, and low if the socioeconomic system is poorly preserved. (2) Dynamic socioeconomic resilience (Dresilience; Hertzler and Harris, unpublished manuscript) was measured by the speed of recovery after a shock, i.e., the expected time until a system switches from one system state to another. A disturbance can create opportunity for innovation, new activities, and development (Berkes et al. 2002, Gunderson and Holling
2002, Folke 2006), avoiding potentially dramatic social consequences. The ability to exit or to diversify and innovate may fall into this type of resilience. The D-resilience captured the speed of recovery, evaluated as high (several days or weeks), medium (several months), or low (several years).

\section{Governing resilience}

Governing resilience (G-resilience) was defined to represent decisions at the community or public policy levels to mitigate disruption to business after a perturbation (Kajitani and Tatano 2009). Four key attributes by which management of marine systems can successfully support resilience are: (1) embracing uncertainty and change (capacity for innovation and use of disturbances as opportunity); (2) building knowledge and understanding of resource and ecosystem dynamics; (3) developing management practices that measure, interpret, and respond to ecological feedback; and (4) supporting flexible institutions and social networks in multilevel governance systems (Hughes et al. 2005). These governing attributes were used to assess short-term G-resilience (STG-resilience) and long-term Gresilience (LTG-resilience). STG-resilience reflects the collective capacity to cope with disturbances with existing institutions (effective resource management with rapid and appropriate responses to a crisis situation). A Low STG-resilience score is associated with a lack of management institutions and collective organization, the absence of management rules, a protracted decision-making process (several months to years), or a mismatch of existing institutions and rules with the system to be governed (i.e., a scale problem between the drivers affecting the ecological system and the decision-making level). These make the system difficult to govern (Bavinck et al. 2013). Conversely, a higher STGresilience score will be achieved if formal and informal rules play an important role in the governance of the marine system. LTGresilience concerns the ability to reform the institutions and strengthen the adaptive capacity of the system in the long run by building new knowledge and practices in response to ecological feedback, creating social networks, reforming institutions toward flexible management committees and rules, solving conflicts, devolving social power, and raising funds to address the issue. A high LTG-resilience score is supported by a high level of research and development directed at the social ecological system, strong compliance with and participation of end-users in new management rules (e.g., comanagement), a multilevel governance system able to adjust the institutional response to the severity of external shocks, and the financial support by regional or national authorities to address the issue. A low LTG-resilience score is given if none of these efforts and changes are made, and a medium score if only part of this long-term investment is made.

\section{Multidimensional resilience framework and index}

An appraisal framework of the responses implemented to cope with a critical issue such as MMB affecting the marine or coastal system was developed by combining all the dimensions of resilience (Fig. 1). The scoring for the six resilience axes of the MRF was based on information from the I-ADApT framework, which is designed to provide a rapid appraisal of responses to global change issues affecting local marine social-ecological systems by building on knowledge learned from past experience (Bundy et al. 2016). For each case study (Table 1), it includes: (1) descriptions of the natural, social, and governing systems, and responses by each to a perturbation; (2) appraisal of the responses; 
Table 1. List of mass mortalities of bivalves case studies analysed.

\begin{tabular}{|c|c|c|}
\hline Case study & Issue & Expert consulted \\
\hline Matsushima Bay, Japan & $\begin{array}{l}\text { Recent increase in norovirus-polluted oysters after the tsunami of } 11 \\
\text { March } 2011 \text { and coincident with the increase in norovirus-affected patients } \\
\text { in winter }\end{array}$ & $\begin{array}{l}\text { Dr. Tetsuo (SEKI, Japan Fisheries } \\
\text { Science and Technology } \\
\text { Association) }\end{array}$ \\
\hline Chesapeake Bay (Mouth of the & Appearance of the parasites known as MSX (Haplosporidium nelsoni) and & Professor George Santopietro \\
\hline Rappahannock River), USA & $\begin{array}{l}\text { Dermo (Perkinsus marinus), causing long-term declines in native oysters } \\
\text { (Crassotrea virginica) in the } 1960 \mathrm{~s}\end{array}$ & $\begin{array}{l}\text { (Radford University), Kurt } \\
\text { Stephenson (Virginia Tech), and } \\
\text { James Wesson (Virginia Marine } \\
\text { Research Commission) }\end{array}$ \\
\hline Puget Sound, Washington, USA & $\begin{array}{l}\text { Poor harvests on the U.S. Pacific Northwest coast (Washington and } \\
\text { Oregon coasts); decalcification and killing of oyster spat in hatcheries } \\
\text { caused by acidification between } 2005 \text { and } 2009\end{array}$ & $\begin{array}{l}\text { Professors Eddie Allison, Jack } \\
\text { Cheney, and Ryan Kelly (University } \\
\text { of Washington), and Sarah Cooley } \\
\text { (Ocean Conservancy) }\end{array}$ \\
\hline $\begin{array}{l}\text { La Coronilla-Barra del Chuy, } \\
\text { Rocha, Uruguay }\end{array}$ & $\begin{array}{l}\text { Mass mortalities in the populations of yellow clam (Mesodesma } \\
\text { mactroides) along its entire geographic range since 1994; the mass } \\
\text { mortalities have been attributed to a number of factors, namely positive } \\
\text { sea temperature anomalies, harmful algal blooms, environmental stress, } \\
\text { artificial freshwater canal discharge, parasites, and storms }\end{array}$ & $\begin{array}{l}\text { Professor Omar Defeo (Universidad } \\
\text { de la Republica, Facultad de } \\
\text { Ciencias) }\end{array}$ \\
\hline Bay of Quiberon, Atlantic coast, & Massive mortality and decreased growth of farmed oysters in summer & Dr. Joseph Mazurié (Ifremer, La \\
\hline France & 2006 because of local hypoxia near the bottom where oysters are cultivated & $\begin{array}{l}\text { Trinité-sur-Mer) and Véronique Le } \\
\text { Bihan (PhD student at University of } \\
\text { Nantes) }\end{array}$ \\
\hline $\begin{array}{l}\text { Bay of Bourgneuf, Atlantic coast, } \\
\text { France }\end{array}$ & $\begin{array}{l}\text { From summer } 2008 \text { onwards, mass mortality of oyster larvae and juveniles } \\
\text { of farmed oysters (Crassostrea gigas) with very high mortality rates } \\
\text { (between } 40 \text { and } 100 \% \text { ) because of the presence of oyster herpesvirus type } 1 \\
\text { (OsHV-1) and Vibrio spp. }\end{array}$ & $\begin{array}{l}\text { Patrice Guillotreau, Véronique Le } \\
\text { Bihan, and Sophie Pardo } \\
\text { (University of Nantes) }\end{array}$ \\
\hline
\end{tabular}

and (3) a typology showing emergent classes of similar response situations. A common case study template (http://www.imber. info) comprising 30 questions relating to the natural, social, and governing systems was designed to collect comparable information from case studies. A summary of the six completed MMB case studies' templates is included in Appendix 1 (Tables A and B). The I-ADApT templates were completed by experts with long-standing experience in their marine systems.

Fig. 1. The multidimensional resilience framework. The static dimensions are located on the left, and the dynamic dimensions on the right; short- and long-term governing resilience are located at the top and bottom, respectively. The green line depicts a system with a maximum level of resilience for every factor (=3, or high), increasing the likelihood of successful responses.

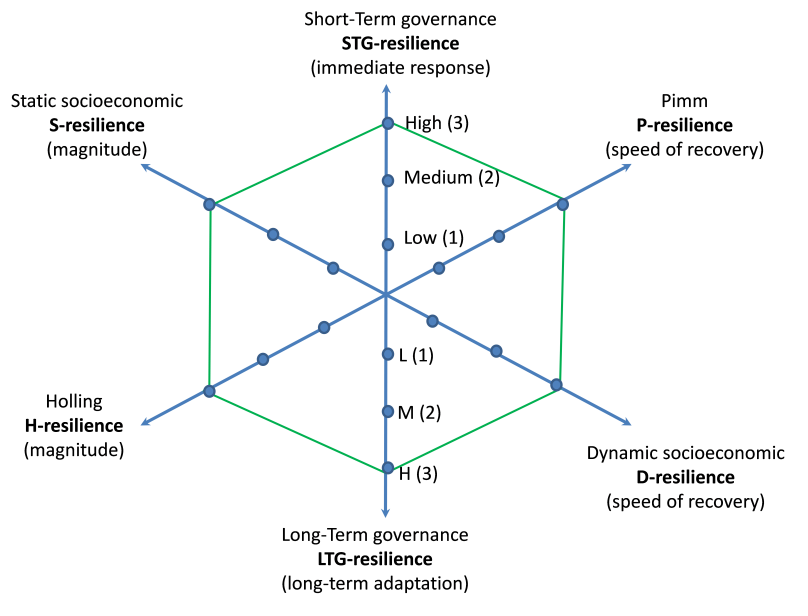

From these responses, a scoring system for the six MRF dimensions (Table $\mathrm{C}$ in Appendix 1) was developed through a Delphi method (Dalkey and Helmer 1963). The final score was obtained by averaging independent choices made by the coauthors. Because interpretations of resilience criteria could sometimes give heterogeneous results, a Monte Carlo approach was used to draw randomly dimension values from a uniform law within the range of minimum and maximum values given by coauthors, and 500 trials of the MRI index were run for each case study, resulting in a distribution of the index value rather than a single average score.

On the basis of scores (valued between 1 and 3 ) for each axis, a resilience composite indicator, called the multidimensional resilience index (MRI) was computed for each social-ecological system by calculating the hexagonal area resulting from the six resilience measures. To calculate the polygon area, we first numbered the vertices in order (clockwise or counter-clockwise) starting at any vertex. Given that zero is the origin of the polygon, we consider two vectors $a$ and $b$ going from the origin to the first two vertices. The norm of the vectorial product $a \times b$ gives the area of a parallelogram passing symmetrically through the two vertices. The polygon area is given by the sum of all parallelogram areas and divided by 2 . If we denote $x_{1}$ as the $x$ coordinate of vertex 1 , and $y_{\mathrm{n}}$ as the coordinate of the $n$th vertex, the area is given by the formula:

$$
\left|\frac{\left(x_{1} y_{2}-y_{1} x_{2}\right)+\left(x_{2} y_{3}-y_{2} x_{3}\right)+\cdots+\left(x_{n} y_{1}-y_{n} x_{1}\right)}{2}\right|
$$

The hexagonal area was then standardized over the maximum value if all dimensions had high scores (minimum area $=3$; maximum area $=27$ ). This results in an index of resilience 
standardized between 0 and 1 ([MRI - MRI $\left.{ }_{\min }\right] /\left[\mathrm{MRI}_{\max }-\right.$ $\left.\mathrm{MRI}_{\min }\right]$ ); the closer the index is to unity, the more resilient the system is. Despite potential criticism of a composite indicator (e.g., underlying assumptions regarding the substitutability and weights between the components; Klugman et al. 2011), it captures, in a snapshot, a complex and multidimensional reality and is often easier to understand for decision makers than is a bundle of separate indicators (OECD and JRC 2008).

\section{RESULTS}

\section{Overview of causes and responses}

Causes of MMB in the six case studies include viruses, parasites, predators, hypoxia, acidification, algal blooms, freshwater discharge, and their various combinations. These proximate causes are not always the primary cause. Sewage discharges can result in virus outbreaks (e.g., Matsushima Bay after the March 2011 tsunami). Increasing temperatures and imports of exotic species result in opportunistic pathogens and predators (e.g., Bay of Quiberon, Bay of Bourgneuf, Chesapeake Bay). The combination of variation in localized upwelling of lower $\mathrm{pH}$ deep water and a rising trend in atmospheric $\mathrm{CO}_{2}$ concentration that lowers global ocean $\mathrm{pH}$ result in ocean acidification (e.g., Puget Sound).

Given the diverse causes of MMB and their pathologies within the various ecosystems, the spatial effects (e.g., worldwide spread of oyster herpesvirus type 1, regional ocean acidification by upwelling water along the U.S. Pacific Northwest coast, local pollution in Japan), and production effects (from several to thousands of tonnes) should not be expected to be equivalent. The number of threatened jobs, for example, varied widely among the case studies (between 30 and 3000). In the U.S. Pacific Northwest, some bivalve farmers decided to leave the area, but for the most part, the industry in that case study has remained stable. In Matsushima Bay, the number of jobs has declined by $7 \%$ since 2011 (from 121 to 112). In Quiberon, a system hit by two sequential disasters (hypoxia in 2006 and pathogens since 2008), most of the oyster farmers have left the Bay (from 60 in 2005 to 10 several years after) to settle elsewhere (J. Mazurier, personal communication). In Barra del Chuy, the fishery was closed between 1993 and 2007, causing some fishers to move to other industries before the fishery reopened.

Despite this heterogeneous set of causes and consequences, common responses can be observed across the case studies (Fig. 2 and Table B in Appendix 1). In the Bay of Bourgneuf case, the $\mathrm{H}$ - and P-resilience are fairly low because monoculture resulted in a lack of biodiversity, although ecosystems can maintain their function with lower stocks of bivalves after an epizootic outbreak. S- and D-resilience are rather high because farmers proved able to adapt rapidly after every outbreak, in particular, by implementing substantial changes in practices (e.g., new species, new leaseholds for natural spat, more purchasing of triploid spat from hatcheries). However, S-resilience would have been severely reduced without important public funds. STGresilience is rather low despite the multilevel governing structure (from national to regional management institutions). Collective action is poorly developed so that new management measures have been few and limited, although a ban on interbasin transfers of animals was implemented. The medium score of LTG governance is explained by the public efforts in support of research on the nature and causes of the virus outbreak, not by the industrial capacity of reforming institutions.

Fig. 2. The multidimensional resilience framework applied to six case studies of mass mortalities of bivalves. The polygons display the average resilience scores assigned by the coauthors and experts ( $1=$ low, 2 = medium, $3=$ high $)$ along six resilience axes for each case study.

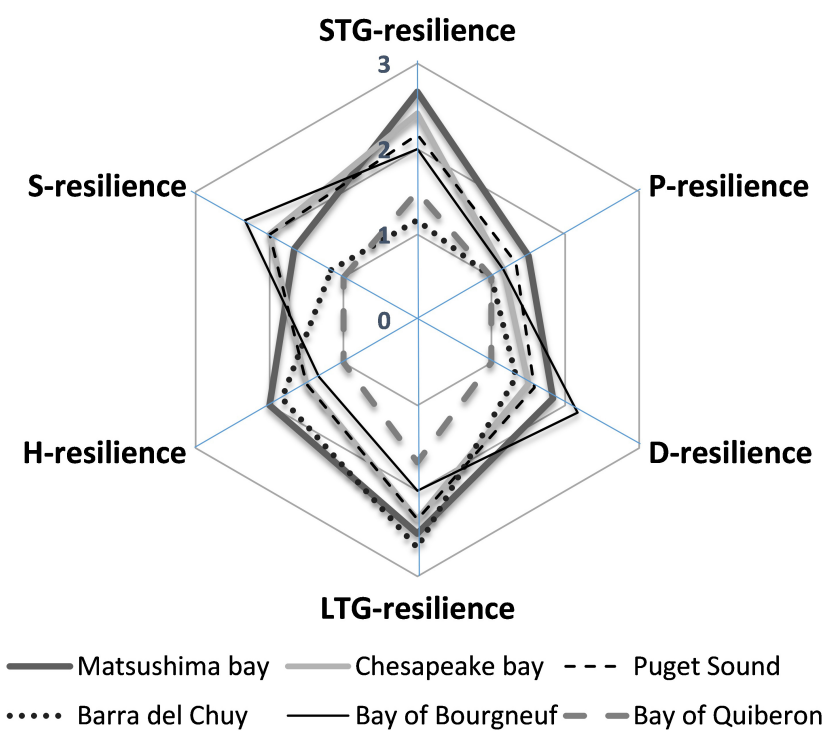

In the case of MMB in the Bay of Quiberon case, all types of resilience are low, and no adaptive response was possible because of changes in natural characteristics within the Bay (i.e., hypoxia). The magnitude of the shock could be considered too high to sustain any kind of shellfish farming activity. Most farmers had to leave the Bay, with some able to stay in business by acquiring new leaseholds in other basins.

In Matsushima Bay, authorities were very responsive after the tsunami event, funding a substantial investment in sewage facilities, which included a norovirus inactivating function. Nonetheless, with long-term and uncertain effects for the industry, the S-resilience is rated as low. Farmers also adapted rapidly to the new situation but still suffered a dramatic decline in their income because of a fall in the value of shelled oysters due to norovirus infection.

In Barra del Chuy, the decision to close the fishery and the lack of mitigation measures by the government after the MMB led fishers to quit the yellow clam fishery (low S- and D-resilience). The natural system took almost two decades to recover after the MMB (low P-resilience) but is proving to be robust to shocks (Hresilience) as stricter management measures are taken (yellow clam population has been recovering gradually).

In Chesapeake Bay, the natural conditions make this system highly vulnerable to many threats, explaining weak $\mathrm{H}$ - and $\mathrm{P}$ resilience levels. The emergence of pathogens dates back to the early 1960 s, and the system has only started to recover recently after an ambitious replenishment program and management plan were implemented starting in 2000. 
In Puget Sound, the industry and government undertook good short-term responses to cope with ocean acidification affecting oyster larvae, even at high costs (high S- and D-resilience).

The differences along the six axes were tested using mean difference t-tests at the 5\% significance level. The test results isolate two case studies from the others: the Bay of Quiberon and Barra del Chuy. Concerning the STG scores, the null hypothesis of different means is accepted between these two cases and the four others. A similar result is found for the static economic resilience. For the other types of resilience, the results are not as clear. Note that this test of difference on means is not possible when experts are unanimous regarding the scores because the standard deviation is null.

\section{Appraisal of case study responses}

The MRI was computed using a Monte Carlo approach: with 500 trials for each case study, the resilience scores of every dimension were randomly drawn and combined between the lowest and highest value proposed independently by the six coauthors. This procedure allows the uncertainty surrounding the scoring process to be considered. The ratio between the polygon area and the maximum area obtained if all dimensions had the highest 3-point score has also been preferred to an average resilience score across the six dimensions to emphasize the situations close to the critical levels of resilience. For instance, an average score of 2 (i.e., halfway between the minimum 1 and maximum 3 values) across the six dimensions would give a value of 0.5 using a simple arithmetic average index (halfway between 0 and 1), but only 0.375 using a standardized hexagonal area index.

The semiopen Bay of Quiberon has the lowest score (0.05) and the smallest range of uncertainty $(50 \%$ of trials fell between 0.04 and 0.07 ), meaning that experts largely agree on the scoring (Fig. 3 ): the natural conditions have been degraded in the last few decades with less primary productivity and oxygen. In this bay, hydrological and weather conditions have changed (heat, northwest wind regime, local upwelling causing thermal stratification, declines in oxygen and phytoplankton), increasing the bivalve mortality risk. From 60 initial farms, only 10 are still producing in the bay. The average production has decreased from 220 tonnes/farm in 2005-2006 to 70 tonnes/farm in 2010-2011, along with a reduction in employment from 175 to 115 full-time equivalent jobs over the same period. No social or governing responses could sustain the oyster farming activity in such a poor environment.

In contrast, Matsushima Bay has the highest score (0.40), within a range of 0.35 (first quartile) to 0.45 (third quartile; Fig. 3). This relatively high score is mainly explained by the magnitude of short-term and long-term governance (adaptability) because the other dimensions of the MRF depict rather similar (or even lower) values to the other MMB cases. Several approaches have been found to inactivate norovirus in the short term, including heat treatment of shucked oysters. In the long term, the national government has invested massively (\$42 million USD in 2013) in the reconstruction of sewage treatment facilities, which now have virus-inactivating functions. However, the number of farms has declined by $7 \%$ since 2011 , and income levels have been halved because of low prices for heat-treated shucked oysters. Human health problems are solved in the short term, but norovirus is not eliminated, and consumption is therefore reduced, affecting the long-run profitability of farms. The average score for D-resilience has high uncertainty because half of the coauthors gave a low score (1) and the other half the highest one (3), suggesting that these estimates leave room for interpretation. This has been taken into consideration using the Monte Carlo approach.

Fig. 3. Box plots of the estimated multidimensional resilience index for six case studies of mass mortalities of bivalves. $\mathrm{MB}=$ Matsushita Bay, PS = Puget Sound, BB = Bay of Bourgneuf, $\mathrm{CB}=$ Chesapeake Bay, BdC = Barra del Chuy, $\mathrm{BQ}=$ Bay of Quiberon. The midline indicates the median, the box indicates the first and third quartiles of the distribution, whiskers indicate the minimum and maximum values, and circles represent outliers. All statistics are available in Appendix 1, Table D.

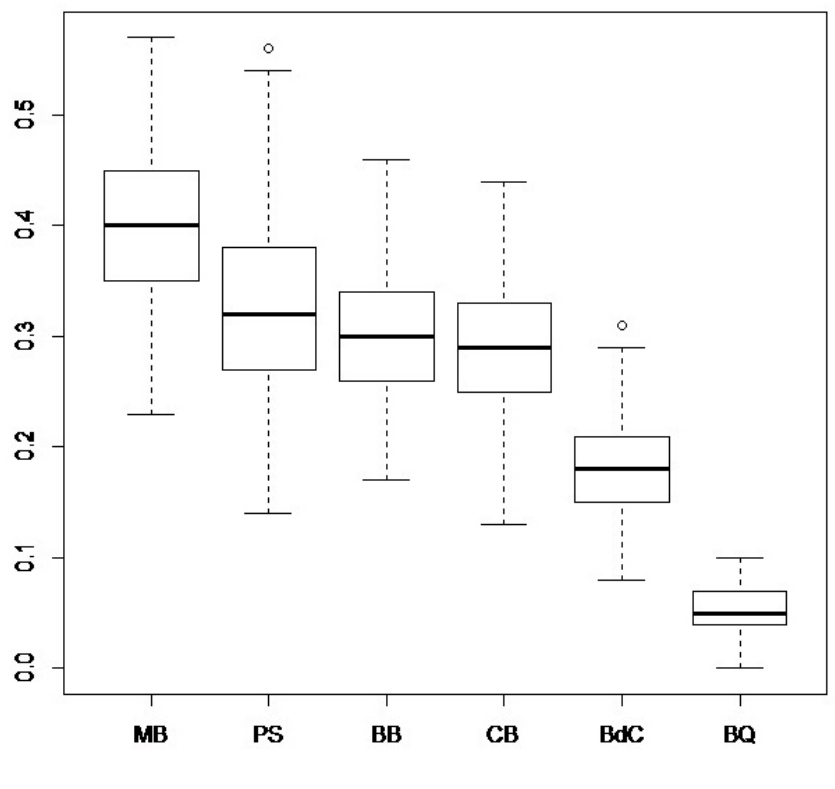

The remaining four marine bivalve systems are intermediate to these predecing two situations, with median scores of $0.32,0.30$, and 0.29, respectively, for Puget Sound, Bay of Bourgneuf, and Cheseapeake Bay, but a much lower score of 0.18 for Barra del Chuy, where the fishery was closed for 14 years (Fig. 3). For the first three systems, responses have been immediate and strong enough to cope with the socioeconomic issues in the short run, maintaining activity levels. However, issues are not solved in the long run, and the future of such systems is still under major threat.

In the Bay of Bourgneuf, the causes of MMB are still unknown, and some hypotheses (e.g., climate change, ocean acidification) are under investigation. No resistant species have been found despite various trials with imported oysters and local wild oysters. Bivalve production has been reduced by $30 \%$ since the virus outbreak, and many oyster producers who were close to retirement age or were weakly involved in this activity have left the industry. The remaining oyster farms were still facing very high mortality rates eight years after the beginning of the perturbation. The farmers were able to cope with this issue because of state financial compensation, increasing purchases of 
hatchery spat (particularly triploid seeds), higher market prices, and new practices (upper foreshore or deeper, new leaseholds to collect natural spat, diversification in other species such as mussels and algae).

In Chesapeake Bay, state intervention played a key role in the industrial recovery. A large-scale restoration program (Virginia Oyster Heritage Program) was initiated in 1999, and artificial reefs were built in 2001 with intensive shell replenishment (total cost of \$2.4 million USD). The state also established a rotational ground opening scheme (with controlled season time and length, daily limits, and cull size set annually), created brood stock sanctuaries (no-take zones), and limited gear (only hand scrapes). The natural adaptive capacity of the system remains poor because of its high vulnerability to changes (presence of diseases such as MSX and Dermo, predation by whelks and rays, fresh water flow from storms, pollution levels, and sedimentation), which reduce the population size by approximately $50 \%$ per year. The large investment has nonetheless increased oyster populations on shelled grounds, achieving harvest levels in 2013 higher than those in the last 26 years. An undesired outcome of this success has been the increasing number of regulations violations (oystering at night, harvesting without a license, taking undersized oysters).

In Puget Sound, low-pH waters hinder calcification in shellproducing marine organisms. Under the Washington Shellfish Initiative, a temporary group, the Blue Ribbon Panel, was formed by gathering major stakeholders and was charged with suggesting management strategies to deal with the ocean acidification issue, with the assistance of a scientific group from the University of Washington. The Blue Ribbon Panel produced 42 policy recommendations and 18 key actions for reducing the effects of ocean acidification. This comprehensive study helped advocate for more fundraising, policy making, and awareness of ocean acidification-related issues. Technical measures have allowed farmers to cope with the ocean acidification problem by pumping higher-pH water and raising spat on shore at the larval stage before growing them in the open water. However, the industry expects that operating costs will continue to rise because of such changes in rearing practices.

In Barra del Chuy, ranked halfway between the previous group of three and the Bay of Quiberon, management authorities closed the yellow clam fishery from 1993 until 2007, almost immediately after the mass mortality outbreak (Ortega et al. 2016), but no options were provided to the fishers to mitigate the economic impact on their livelihoods. Consequently, fishers had to find alternative jobs in other industries (e.g., agriculture, construction). The natural system took almost two decades to recover after the $\mathrm{MMB}$, but production is not back to pre-MMB levels. After the fishery reopened, in 2008-2009, a stricter comanagement system was implemented, with monthly total allowable catch, individual quotas, restricted numbers of licenses, minimum oyster size, closed season, and spatial measures. This fishery exhibits strong long-term governing resilience through a remarkable capacity to learn and adapt bolstered by the high level of scientific knowledge about this system.

\section{DISCUSSION}

Comparison of the resilience polygons across case studies gave insights into systems that may succeed in the future. The MRF results and tests of mean difference show at least two separate groups: Quiberon and Barra del Chuy, with lower scores; and Matsushima Bay, Bourgneuf Bay, Puget Sound and Chesapeake Bay, with higher scores. The main diverging dimensions concern the static economic and the short-term governance dimensions. STG resilience increases with the collective capacity to absorb shocks with existing institutions. In the case of mismatch between the governing system (with its existing institutions and rules) and the system to be governed (because of scale problems or areas of competence), the ability to address the issue is limited. In those case studies where the STG- and LTG-resilience reached higher scores, some of the responses involved compensation measures or restoration plans. In Europe, Japan, and the United States, several million dollars (USD) annually have been spent on national aid schemes to compensate farmers immediately after the crisis or to restore habitats. Projects have included shell replenishment of public grounds in Chesapeake Bay, the public Agriculture Calamity scheme and tax alleviation in France, and financial support from the local government to compensate insurance funds of fisheries cooperatives and subsidies to promote direct marketing in Japan. However, these efforts are not sufficient because the social response is missing some key principles of resilience (Biggs et al. 2015) such as maintaining diversity and redundancy, managing the slow variables and feedback effects (such as ocean acidification and pathogens), understanding social-ecological systems as complex adaptive systems, broadening participation, and promoting polycentric governance systems (where "polycentricity consists of multiple governing authorities that interact across different levels of the policy process" [Ostrom 2010]). Substantial financial effort to maintain the industry has not been adopted in Uruguay, a developing country that cannot afford such an expensive policy for a single and limited community; however, the reopening of the fishery after 14 years of closure has been marked by a complete change of management rules.

Changes in rules and practices were observed and found to be common in many case studies. Several management measures for fisheries and more technical measures for aquaculture were applied. Long-term responses dealing with slow variables were also forthcoming at many sites as prevention measures, including public awareness campaigns and development of early warning systems for ocean acidification, sanitary inspection systems, and monitoring systems for water and oyster quality. However, some other measures were more issue specific and localized, such as the introduction of new or resistant species, which is distinguished from a change in practices because of its unknown long-term consequences for the ecosystem (McKindsey et al. 2007, Padilla 2010). Similarly, chemical or physical solutions such as heat, filtration, or natural chemical treatment are only suitable in particular situations and are associated with much higher costs (water filtration or $\mathrm{pH}$ altering techniques, on-shore rearing techniques, better triage of dead bivalves, etc.).

The analysis of these case studies suggests that elongated hexagons prevail (Fig. 2), meaning that both short-term and longterm responses are effective but hardly cope with the issue in the long run because of the lower scores on other resilience dimensions. Most case studies refer to coastal temperate systems in shallow waters, which are highly transformed by intensive oyster monoculture. The natural system of bivalve farming in temperate shallow waters is perhaps not robust enough to absorb 
severe shocks (e.g., because of pollution or acidification, hence low H-resilience), but may recover rapidly if the social response is vigorous immediately following the perturbation event (e.g., construction of sewage facilities, hence relatively high P-resilience in the Matsushima case, or quarantine period). Biodiversity and the number of trophic levels are rather low in such human-made environments (McArthur 1955, McCann et al. 2000), particularly with frequent shocks such as disease, pollution, and heat waves affecting bivalve production (Glude 1975, Lafferty et al. 2004). This lack of diversity breaks the first principle of ecosystem resilience established by Biggs et al. (2012, 2015). It raises questions about the future of such monospecific culture systems facing new hazards. The recent degradation of natural conditions with increasing temperatures and ocean acidification has reduced the natural resilience of these coastal systems (Harvell et al. 1999, Cassis et al. 2011, Domeneghetti et al. 2014, Ekstrom et al. 2015). Ecosystems could deteriorate in the future because of increasing $\mathrm{CO}_{2}$ and ocean acidification. Removing filter-feeding bivalves can result in an organic algae takeover, further altering water quality and the whole food web (Jokiel et al. 2008, Padilla 2010).

We showed that low natural resilience can be partly compensated by strong social innovation and protective governing systems (state aid, public research, replenishment plans), at least in the short and medium terms. Oyster farming social systems, sometimes created more than a century ago, proved to be resilient after several episodes of dramatic depletion (Grizel and Héral 1991, Ewart and Ford 1993, Renault 2011), but caused greater dependence on a single species (C. gigas; McKindsey et al. 2007, Padilla 2010) and hatchery technology (triploid seeds). Such a strategy has steadily reduced redundancies and diversity in the system, ignoring a key principle of social-ecological resilience (Walker and Salt 2006, 2012, Biggs et al. 2012, 2015). The periodic occurrence of crises in recent years, particularly since the proliferation of pathogen outbreaks in the late 20th century (Harvell et al. 1999, Matsuyama 1999, Cheney et al. 2000, EFSA 2010), reveals this weakness and puts the future of this industry in jeopardy.

\section{CONCLUSION}

We evaluated the responses provided by the social and governing systems to multiple issues causing MMB around the world. A systems approach was adopted that considers the linkages among the natural, social, and governing systems. We used two frameworks (I-ADApT and MRF) to collect and process data related to six MMB case studies. The concept of resilience was used analyze the capacity of marine systems to recover after severe external shocks along six dimensions: ecological, social, and governance, both in the short and long term. The developed MRF was particularly flexible and informative as an appraisal tool of responses, and the estimated MRI allowed us to compare the six MMB case studies with respect to their ability to recover after the shock.

Various responses across all case studies were able to save the industry in the short term in most cases, without restoring the long-term resilience of the natural coastal systems. The natural systems share common characteristics (poor biodiversity and biophysical conditions) and were degraded prior to the MMB events. The social and governing responses have been fairly creative and substantial, including technical innovations, preventive measures, management rules, financial aid, and support for public research. Although the responses succeeded in keeping the industries afloat in the short term, the underlying causes behind the MMB issues were often not discovered, and the sustainability of the social-ecological systems was not ensured in the long term. The presence of pathogens in at least three case studies (Chesapeake Bay, Bay of Bourgneuf, Bay of Quiberon) and the risk of ocean acidification in Puget Sound represent slow variables that are monitored but not fully understood, breaking at least two resilience principles defined by Biggs et al. (2012, 2015).

A resilient system ideally integrates both short- and long-term components. To prepare socioeconomic systems in advance of environmental change, general coping strategies could be developed with explicit current and future plans to be implemented stepwise in the event of a socioeconomic shock. To develop these integrated strategies so that they are effective for the social and ecological parts of the system, a range of stakeholders should be included and involved in an iterative process. At the same time, economic or risk-benefit scenarios could be developed that compare the effect of progressively enhancing resilience to ad-hoc responses carried out piecemeal, which can be costly or maladaptive. The case studies explored here show specific ways in which resilience can be enhanced to mitigate the consequences of MMB events. The analytical approach that we developed and demonstrated can be applied to identify weaknesses in the resilience of social-ecological system that need to be addressed.

Responses to this article can be read online at: http://www.ecologyandsociety.org/issues/responses. $\mathrm{php} / 9084$

\section{Acknowledgments:}

We are very grateful to Jack Cheney, Ryan Kelly, Kurt Stephenson, James Wesson, and Joseph Mazurié for their significant contributions to the bivalve mass mortality survey, and to Romain Duret (student at the University of Nantes) for his extensive review of the literature on bivalve mass mortality. This research was financially supported by the international IMBER program (www. imber.info) and the French ANR-GIGASSAT research project (www.gigassat.org/).

\section{LITERATURE CITED}

Anderson, J. L. 2002. Aquaculture and the future: why fisheries economists should care. Marine Resource Economics 17 (2):133-151. [online] URL: http://www.jstor.org/stable/42629357

Bavinck, M., R. Chuenpagdee, S. Jentoft, and J. Kooiman, editors. 2013. Governability of fisheries and aquaculture: theory and applications. Springer, Dordrecht, The Netherlands. http://dx. doi.org/10.1007/978-94-007-6107-0

Béné, C. 2013. Towards a quantifiable measure of resilience. IDS Working Paper 434. Institute of Development Studies, Brighton, UK. [online] URL: http://opendocs.ids.ac.uk/opendocs/

bitstream/123456789/2990/1/Wp434.pdf 
Berkes, F. 2011. Restoring unity: the concept of marine socialecological systems. In R. E. Ommer, R. I. Perry, K. Cochrane, and P. Cury, editors. World fisheries: a social-ecological analysis. Wiley-Blackwell, Oxford, UK. http://dx.doi.org/10.1002/9781444392241. $\underline{\mathrm{ch} 2}$

Berkes, F., J. Colding, and C. Folke, editors. 2002. Navigating social-ecological systems: building resilience for complexity and change. Cambridge University Press, Cambridge, UK. http://dx. doi.org/10.1017/cbo9780511541957

Berkes, F., and C. Folke. 1998. Linking social and ecological systems for resilience and sustainability. Pages 13-20 in F. Berkes and C. Folke, editors. Linking social and ecological systems: management practices and social mechanisms for building resilience. Cambridge University Press, Cambridge, UK.

Biggs, R., M. Schlüter, D. Biggs, E. L. Bohensky, S. BurnSilver, G. Cundill, V. Dakos, T. M. Daw, L. S. Evans, K. Kotschy, A. M. Leitch, C. Meek, A. Quinlan, C. Raudsepp-Hearne, M. D. Robards, M. L. Schoon, L. Schultz, and P. C. West. 2012. Toward principles for enhancing the resilience of ecosystem services. Annual Review of Environment and Resources 37:421-448. http:// dx.doi.org/10.1146/annurev-environ-051211-123836

Biggs, R., M. Schlüter, and M. L. Schoon, editors. 2015. Principles for building resilience: sustainable ecosystem services in socialecological systems. Cambridge University Press, Cambridge, UK. http://dx.doi.org/10.1017/cbo9781316014240

Brazeiro, A., and O. Defeo. 1999. Effects of harvesting and density dependence on the demography of sandy beach populations: the yellow clam Mesodesma mactroides of Uruguay. Marine Ecology Progress Series 182:127-135. http://dx.doi.org/10.3354/meps182127

Bundy, A., R. Chuenpagdee, S. R. Cooley, O. Defeo, B. Glaeser, P. Guillotreau, M. Isaacs, M. Mitsutaku, and R. I. Perry. 2016. A decision support tool for response to global change in marine systems: the IMBER-ADApT framework. Fish and Fisheries 17 (4):1183-1193. http://dx.doi.org/10.1111/faf.12110

Burdon, D., R. Callaway, M. Elliott, T. Smith, and A. Wither. 2014. Mass mortalities in bivalve populations: a review of the edible cockle Cerastoderma edule (L.). Estuarine, Coastal and Shelf Science 150:271-280. http://dx.doi.org/10.1016/j.ecss.2014.04.011

Carpenter, S., B. Walker, J. M. Anderies, and N. Abel. 2001. From metaphor to measurement: resilience of what to what? Ecosystems 4:765-781. http://dx.doi.org/10.1007/s10021-001-0045-9

Cassis, D., C. M. Pearce, and M. T. Maldonado. 2011. Effects of the environment and culture depth on growth and mortality in juvenile Pacific oysters in the Strait of Georgia, British Columbia. Aquaculture Environment Interactions 1(3):259-274. http://dx.doi. org/10.3354/aei00025

Castinel, A., N. Dhand, L. Fletcher, A. Rubio, M. Taylor, and R. Whittington. 2015. OSHV-1 mortalities in Pacific oysters in Australia and New Zealand: the farmer's story. Cawthron Institute Report 2567. Cawthron Institute, Nelson, New Zealand. [online] URL: http://www.cawthron.org.nz/media_new/publications/pdf/2015_09/ CR2567printable.pdf

Cheney, D. P., B. F. MacDonald, and R. A. Elston. 2000. Summer mortality of Pacific oysters Crassostrea gigas (Thunberg): initial findings on multiple environmental stressors in Puget Sound, Washington, 1998. Journal of Shellfish Research 19(1):353-359.

Crutzen, P. J., and E. F. Stoermer. 2000. The "Anthropocene." Global Change Newsletter 41:17-18. [online] URL: http://www. igbp.net/download/18.316f18321323470177580001401/1376383088452/ NL41.pdf

Dalkey, N., and O. Helmer. 1963. An experimental application of the Delphi method to the use of experts. Management Science 9 (3):458-467.

Di Salvo, L. H., J. Blecka, and R. Zebal. 1978. Vibrio anguillarum and larval mortality in a California coastal shellfish hatchery. Applied and Environmental Microbiology 35(1):219-221. [online] URL: http://aem.asm.org/content/35/1/219.full.pdf+html

Domeneghetti, S., L. Varotto, M. Civettini, U. Rosani, M. Stauder, T. Pretto, E. Pezzati, G. Arcangeli, E. Turolla, A. Pallavicini, and P. Venier. 2014. Mortality occurrence and pathogen detection in Crassostrea gigas and Mytilus galloprovincialis close-growing in shallow waters (Goro lagoon, Italy). Fish and Shellfish Immunology 41(1):37-44. http://dx.doi. org/10.1016/j.fsi.2014.05.023

Ekstrom, J. A., L. Suatoni, S. R. Cooley, L. H. Pendleton, G. G. Waldbusser, J. E. Cinner, J. Ritter, C. Langdon, R. van Hooidonk, D. Gledhill, K. Wellman, M. W. Beck, L. M. Brander, D. Rittschof, C. Doherty, P. E. T. Edwards, and R. Portela. 2015. Vulnerability and adaptation of US shellfisheries to ocean acidification. Nature Climate Change 5:207-214. http://dx.doi. org/10.1038/nclimate2508

Elston, R. A., J. H. Beattie, C. Friedman, R. Hedrick, and M. L. Kent. 1987. Pathology and significance of fatal inflammatory bacteraemia in the Pacific oyster, Crassostrea gigas Thünberg. Journal of Fish Diseases 10(2):121-132. http://dx.doi.org/10.1111/ j.1365-2761.1987.tb00727.x

European Food Safety Authority Panel on Animal Health and Welfare (EFSA). 2010. Scientific opinion on the increased mortality events in Pacific oysters, Crassostrea gigas. EFSA Journal 8(11):1894. http://dx.doi.org/10.2903/j.efsa.2010.1894

Ewart, J. W., and S. E. Ford. 1993. History and impact of MSX and Dermo diseases on oyster stocks in the Northeast region. NRAC Fact Sheet 200. Northeastern Regional Aquaculture Center, University of Massachusetts, Dartmouth, Massachusetts, USA.

Folke, C. 2006. Resilience: the emergence of a perspective for social-ecological systems analyses. Global Environmental Change 16(3):253-267. http://dx.doi.org/10.1016/j.gloenvcha.2006.04.002

Folke, C., S. Carpenter, T. Elmqvist, L. Gunderson, C. S. Holling, B. Walker, J. Bengtsson, F. Berkes, J. Colding, K. Danell, M. Falkenmark, L. Gordon, R. Kasperson, N. Kautsky, A. Kinzig, S. Levin, K.-G. Mäler, F. Moberg, L. Ohlsson, E. Olsson, E. Ostrom, W. Reid, J. Rockström, H. Savenije, and U. Svedin. 2002. Resilience and sustainable development: building adaptive capacity in a world of transformations. Scientific Background Paper on Resilience for the process of The World Summit on Sustainable Development on behalf of The Environmental Advisory Council to the Swedish Government. Environmental Advisory Council, Ministry of the Environment, Stockholm, Sweden. [online] URL: http://era-mx.org/biblio/resilience-sd.pdf 
Folke, C., S. R. Carpenter, B. Walker, M. Scheffer, T. Chapin, and J. Rockström. 2010. Resilience thinking: integrating resilience, adaptability and transformability. Ecology and Society 15(4):20. [online] URL: http://www.ecologyandsociety.org/vol15/iss4/ $\underline{\operatorname{art} 20 /}$

Folke, C., T. Hanh, P. Olsson, and J. Norberg. 2005. Adsaptive governance of social-ecological systems. Annual Review of Environment and Resources 30:441-473. http://dx.doi.org/10.1146/ annurev.energy.30.050504.144511

Food and Agriculture Organization (FAO). 2016. FishstatJ: software for fishery statistical time series. FAO Fisheries and Aquaculture Department, Rome, Italy. [online] URL: http:// www.fao.org/fishery/statistics/software/fishstatj/en

Friedman, C. S., and R. P. Hedrick. 1991. Pacific oyster nocardiosis: isolation of the bacterium and induction of laboratory infections. Journal of Invertebrate Pathology 57 (1):109-120. http://dx.doi.org/10.1016/0022-2011(91)90047-T

Glude, J. B. 1975. A summary report of Pacific coast oyster mortality investigations 1965-1972. Pages 1-28 in Proceedings of the Third U.S.-Japan Meeting on Aquaculture at Tokyo, Japan. Fishery Agency, Tokyo, Japan.

Grizel, H. 1983. Impact de Marteilia refringens et de Bonamia ostreae sur l'ostréiculture bretonne. International Council for the Exploration of the Sea, Copenhagen, Denmark. [online] URL: http://archimer.ifremer.fr/doc/1983/acte-5924.PDF

Grizel, H., and M. Héral. 1991. Introduction into France of the Japanese oyster (Crassostrea gigas). ICES Journal of Marine Science 47(3):399-403. http://dx.doi.org/10.1093/icesjms/47.3.399

Gunderson, L. H., and C. S. Holling, editors. 2002. Panarchy: understanding transformations in human and natural systems. Island Press, Washington, D.C., USA.

Hallegatte, S. 2014. Economic resilience: definition and measurement. World Bank Policy Research Working Paper 6852. World Bank, Washington, D.C., USA. [online] URL: http:// documents.worldbank.org/curated/en/350411468149663792/pdf/ WPS6852.pdf

Harvell, C. D., K. Kim, J. M. Burkholder, R. R. Colwell, P. R. Epstein, D. J. Grimes, E. E. Hofmann, E. K. Lipp, A. D. M. E. Osterhaus, R. M. Overstreet, J. W. Porter, G. W. Smith, and G. R. Vasta. 1999. Emerging marine diseases - climate links and anthropogenic factors. Science 285:1505-1510. http://dx.doi. org/10.1126/science.285.5433.1505

Hine, P. M., N. Cochennec-Laureau, and F. C. J. Berthe. 2001. Bonamia exitiosus n.sp. (Haplosporidia) infecting flat oysters Ostrea chilensis in New Zealand. Diseases of Aquatic Organisms 47(1):63-72. http://dx.doi.org/10.3354/dao047063

Holling, C. S. 1973. Resilience and stability of ecological systems. Annual Review of Ecology and Systematics 4:1-23. http://dx.doi. org/10.1146/annurev.es.04.110173.000245

Hughes, T. P., D. R. Bellwood, C. Folke, R. S. Steneck, and J. Wilson. 2005. New paradigms for supporting the resilience of marine ecosystems. Trends in Ecology and Evolution 20 (7):380-386. http://dx.doi.org/10.1016/j.tree.2005.03.022
Imaï, T., K. Numachi, J. Oizumi, and S. Sato. 1965. Studies on the mass mortality of the oyster in Matsushima Bay. II. Search for the cause of mass mortality and possibility to prevent it by transplantation experiment. Bulletin of the Tohoku Region Fisheries Research Laboratory 25:27-38.

Jokiel, P. L., K. S. Rodgers, I. B. Kuffner, A. J. Andersson, E. F. Cox, and F. T. Mackenzie. 2008. Ocean acidification and calcifying reef organisms: a mesocosm investigation. Coral Reefs 27(3):473-483. http://dx.doi.org/10.1007/s00338-008-0380-9

Kajitani, Y., and H. Tatano. 2009. Estimation of lifeline resilience factors based on surveys of Japanese industries. Earthquake Spectra 25(4):755-776. http://dx.doi.org/10.1193/1.3240354

Klugman, J., F. Rodríguez, and H.-J. Choi. 2011. The HDI 2010: new controversies, old critiques. Journal of Economic Inequality 9(2):249-288. http://dx.doi.org/10.1007/s10888-011-9178-Z

Lafferty, K. D., J. W. Porter, and S. E. Ford. 2004. Are diseases increasing in the ocean? Annual Review of Ecology, Evolution, and Systematics 35:31-54. http://dx.doi.org/10.1146/annurev. ecolsys.35.021103.105704

Le Bihan, V., S. Pardo, and P. Guillotreau. 2013. Risk perception and risk management strategies of oyster farmers. Marine Resource Economics 28(3):285-304. http://dx.doi. org/10.5950/0738-1360-28.3.285

Liu, J., T. Dietz, S. R. Carpenter, M. Alberti, C. Folke, E. Moran, A. N. Pell, P. Deadman, T. Kratz, J. Lubchenco, E. Ostrom, Z. Ouyang, W. Provencher, C. L. Redman, S. H. Schneider, and W. W. Taylor. 2007. Complexity of coupled human and natural systems. Science 317:1513-1516. http://dx.doi.org/10.1126/ science. 1144004

Lupo, C., A. Osta Amigo, Y. V. Mandard, C. Peroz, and T. Renault. 2014. Improving early detection of exotic or emergent oyster diseases in France: identifying factors associated with shellfish farmer reporting behaviour of oyster mortality. Preventive Veterinary Medicine 116(1-2):168-182. http://dx.doi. org/10.1016/j.prevetmed.2014.05.002

Marshall, N. A., D. M. Fenton, P. A. Marshall, and S. G. Sutton. 2007. How resource dependency can influence social resilience within a primary resource industry. Rural Sociology 72:359-390. http://dx.doi.org/10.1526/003601107781799254

Matsuyama, Y. 1999. Harmful effect of dinoflagellate Heterocapsa cicularisquama on shellfish aquaculture in Japan. Japan Agricultural Research Quarterly 33:283-293.

McArthur, R. H. 1955. Fluctuations of animal populations, and a measure of community stability. Ecology 36(3):533-536. http:// dx.doi.org/10.2307/1929601

McCann, K. S. 2000. The diversity-stability debate. Nature 405:228-233. http://dx.doi.org/10.1038/35012234

McKindsey, C. W., T. Landry, F. X. O'Beirn, and I. M. Davies. 2007. Bivalve aquaculture and exotic species: a review of ecological considerations and management issues. Journal of Shellfish Research 26(2):281-294. http://dx.doi.org/10.2983/0730-8000 (2007)26[281:baaesa]2.0.co;2 
Murray, A. G., M. Marcos-Lopez, B. Collet, and L. A. Munro. 2012. A review of the risk posed to Scottish mollusk aquaculture from Bonamia, Marteilia and oyster herpesvirus. Aquaculture 370-371:7-13.

Mydlarz, L. D., L. E. Jones, and C. D. Harvell. 2006. Innate immunity, environmental drivers, and disease ecology of marine and freshwater invertebrates. Annual Review of Ecology, Evolution, and Systematics 37:251-288. http://dx.doi.org/10.1146/ annurev.ecolsys.37.091305.110103

Nemec, K. T., J. Chan, C. Hoffman, T. L. Spanbauer, J. A. Hamm, C. R. Allen, T. Hefley, D. Pan, and P. Shrestha. 2013. Assessing resilience in stressed watersheds. Ecology and Society 19(1):34. http://dx.doi.org/10.5751/es-06156-190134

Organisation for Economic Co-operation and Development and Joint Research Centre (OECD and JRC). 2008. Handbook on constructing composite indicators: methodology and user guide. OECD Publishing, Paris, France. [online] URL: http://www.oecd. org/std/42495745.pdf

Ortega, L., J. C. Castilla, M. Espino, C. Yamashiro, and O. Defeo. 2012. Effects of fishing, market price, and climate on two South American clam species. Marine Ecology Progress Series 469:71-85. http://dx.doi.org/10.3354/meps10016

Ortega, L., E. Celentano, E. Delgado, and O. Defeo. 2016. Climate change influences on abundance, individual size and body abnormalities in a sandy beach clam. Marine Ecology Progress Series 545:203-213. http://dx.doi.org/10.3354/meps11643

Ostrom, E. 2010. Polycentric systems for coping with collective action and global environmental change. Global Environmental Change 20(4):550-557. http://dx.doi.org/10.1016/j.gloenvcha.2010.07.004

Padilla, D. K. 2010. Context-dependent impacts of a non-native ecosystem engineer, the Pacific oyster Crassostrea gigas. Integrative and Comparative Biology 50(2):213-225. http://dx.doi. org/10.1093/icb/icq080

Palumbi, S. R., K. L. McLeod, and D. Grünbaum. 2008. Ecosystems in action: lessons from marine ecology about recovery, resistance, and reversibility. BioScience 58(1):33-42. http://dx.doi.org/10.1641/b580108

Paul-Pont, I., O. Evans, N. K. Dhand, A. Rubio, P. Coad, and R. J. Whittington. 2014. Descriptive epidemiology of mass mortality due to Ostreid herpesvirus-1 (OsHV-1) in commercially farmed Pacific oysters (Crassostrea gigas) in the Hawkesbury River estuary, Australia. Aquaculture 422-423:146-159. http://dx.doi. org/10.1016/j.aquaculture.2013.12.009

Pernet, F., J. Barret, P. Le Gall, F. Lagarde, A. Fiandrino, A. Huvet, C. Corporeau, P. Boudry, C. Quéré, L. Dégremont, J.-F. Pépin, D. Saulnier, H. Boulet, and H. Keck. 2011. Mortalités massives de l'Huître creuse: causes et perspectives. Rapport final $d u$ programme de recherche sur les mortalités d'huîtres creuses Crassostrea gigas dans l'étang de Thau. RST/LER/LR 11-013. Ifremer, Issy-les-Molineaux, France. [online] URL: http:// archimer.ifremer.fr/doc/00043/15404/12764.pdf

Perry, R. I., R. E. Ommer, M. Barange, S. Jentoft, B. Neis, and U. R. Sumaila. 2011. Marine social-ecological responses to environmental change and the impacts of globalization. Fish and Fisheries 12(4):427-450. http://dx.doi.org/10.1111/j.1467-2979.2010.00402.
Pimm, S. L. 1984. The complexity and stability of ecosystems. Nature 307:321-326. http://dx.doi.org/10.1038/307321a0

Quinlan, A. E., M. Berbés-Blázquez, L. J. Haider, and G. D. Peterson. 2015. Measuring and assessing resilience: broadening understanding through multiple disciplinary perspectives. Journal of Applied Ecology 53:677-687. http://dx.doi.org/10.1111/1365-2664.12550

Renault, T. 2011. A review of mortality outbreaks in the Pacific oyster, Crassostrea gigas, reported since 2008 in various European Union Member States and the related implementation of Council Directive 2006/88/EC. World Organisation for Animal Health, Paris, France. [online] URL: http://www.oie.int/doc/ged/D11038. $\underline{\mathrm{PDF}}$

Resilience Alliance. 2010. Assessing resilience in social-ecological systems: workbook for practitioners. Version 2.0. Resilience Alliance. [online] URL: http://www.resalliance.org/files/

ResilienceAssessmentV2 2.pdf

Rodrigues, L. C., J. C. J. M. Van Den Bergh, F. Massa, J. A. Theodorou, P. Ziveri, and F. Gazeau. 2015. Sensitivity of Mediterranean bivalve mollusc aquaculture to climate change, ocean acidification, and other environmental pressures: findings from a producer survey. Journal of Shellfish Research 34 (3):1161-1176. http://dx.doi.org/10.2983/035.034.0341

Rose, A. 2004. Defining and measuring economic resilience to disasters. Disaster Prevention and Management: an International Journal 13(4):307-314. http://dx.doi.org/10.1108/09653560410556528

Rose, A. 2007. Economic resilience to natural and man-made disasters: multidisciplinary origins and contextual dimensions. Environmental Hazards 7(4):383-398. http://dx.doi.org/10.1016/j. envhaz.2007.10.001

Rose, A., and E. Krausmann. 2013. An economic framework for the development of a resilience index for business recovery. International Journal of Disaster Risk Reduction 5:73-83. http:// dx.doi.org/10.1016/j.ijdrr.2013.08.003

Smith, I. R., J. A. Nell, and R. Adlard. 2000. The effect of growing level and growing method on winter mortality, Mikrocytos roughleyi, in diploid and triploid Sydney rock oysters, Saccostrea glomerata. Aquaculture 185(3):197-205. http://dx.doi.org/10.1016/ S0044-8486(99)00350-6

Soletchnik, P., J. Mazurié, G. Allain, E. Bédier, A. Benabdelmouna, J.-L. Blin, A.-L. Bouquet, H. Cochet, L. Dégremont, F. Gaussem, E. Gervasoni, P. Glize, B. Petton, P.-Y. Roussel, and F. Pernet. 2011. Les pratiques culturales peuvent-elles permettre de réduire la surmortalité du naissain d'huîtres creuses? Récapitulatif des essais d'élevage et expérimentations zootechniques menés sur le territoire français entre 2008 et 2010. RST/LER/PC/ LTB 11-02. Ifremer, Issy-les-Molineaux, France. [online] URL: http://archimer.ifremer.fr/doc/00032/14280/25847.pdf

Soletchnik, P., M. Ropert, J. Mazurié, P. G. Fleury, and F. Le Coz. 2007. Relationships between oyster mortality patterns and environmental data from monitoring databases along the coasts of France. Aquaculture 271(1-4):384-400. http://dx.doi. org/10.1016/j.aquaculture.2007.02.049

Steffen, W., P. J. Crutzen, J. R. McNeill. 2007. The Anthropocene: Are humans now overwhelming the great forces of nature? Ambio 36:614-621. http://dx.doi.org/10.1579/0044-7447 
Turner, B. L. II, R. E. Kasperson, P. A. Matson, J. J. McCarthy, R. W. Corell, L. Christensen, N. Eckley, J. X. Kasperson, A. Luers, M. L. Martello, C. Polsky, A. Pulsipher, and A. Schiller. 2003. A framework for vulnerability analysis in sustainability science. Proceedings of the National Academy of Sciences 100 (14):8074-8079. http://dx.doi.org/10.1073/pnas.1231335100

Walker, B., C. S. Holling, S. R. Carpenter, and A. Kinzig. 2004. Resilience, adaptability and transformability in social-ecological systems. Ecology and Society 9(2):5. http://dx.doi.org/10.5751/ $\underline{\text { es-00650-090205 }}$

Walker, B., and D. Salt. 2006. Resilience thinking: sustaining ecosystems and people in a changing world. Island Press, Washington, D.C., USA.

Walker, B., and D. Salt. 2012. Resilience practice: building capacity to absorb disturbance and maintain function. Island Press, Washington, D.C., USA. http://dx.doi.org/10.5822/978-1-61091-231-0

Xiao, J., S. E. Ford, H. Yang, G. Zhang, F. Zhang, and X. Guo. 2005. Studies on mass summer mortality of cultured zhikong scallops (Chlamys farreri Jones et Preston) in China. Aquaculture 250(3-4):602-615. http://dx.doi.org/10.1016/j.aquaculture.2005.05.002 


\section{APPENDICES}

1) Tables A and B: Application of IADApT to six Mass Mortality of Bivalves (MMB) case studies

2) Table C: List of resilience criteria used for the multidimensional resilience framework and indicator. 


\begin{tabular}{|c|c|c|c|}
\hline Table A & $\begin{array}{c}\text { Barra del Chuy } \\
\text { Yellow clam (M. mactroides) }\end{array}$ & $\begin{array}{c}\text { Puget Sound } \\
\text { Oysters (C. gigas) }\end{array}$ & $\begin{array}{l}\text { Bay of Bourgneuf } \\
\text { Oysters (C. Gigas) }\end{array}$ \\
\hline STRESSORS & $\begin{array}{l}\text { Freshwater discharge (since early 1980s) } \\
\text { Increasing SST anomalies since early } \\
1990 \text { s } \\
\text { Cold winters 2007-08 }\end{array}$ & $\begin{array}{l}\text { Intensifying upwelling events of low- } \\
\mathrm{pH} \text { and high-CO2 water }\end{array}$ & $\begin{array}{l}\text { Increase of SST }\left(+1.5^{\circ} \mathrm{C} \text { since } 1970\right) \text { and } \\
\text { decrease of } \mathrm{pH}(-0.1 \text { over the past } \\
\text { century) } \\
\text { High density of cultured stocks } \\
\text { OsHV-1-mVar since } 1991\end{array}$ \\
\hline $\begin{array}{l}\text { NATURAL SYSTEM } \\
\text { (change-impact) }\end{array}$ & $\begin{array}{l}\text { Erosion and modification of the coastline } \\
\text { (habitat) } \\
\text { Reduced survival, growth and fecundity } \\
\text { rates } \\
\text { Mass mortality since } 1993\end{array}$ & $\begin{array}{l}\text { Water conditions hostile to calcium } \\
\text { carbonate minerals } \\
\text { Massive larval mortality between } \\
2005 \text { and } 2009 .\end{array}$ & $\begin{array}{l}\text { Spillovers of spat } \\
\text { Low yields } \\
\text { Invasive species (crepidula and wild } \\
\text { oysters) } \\
\text { Massive larval mortality since } 2008 \text { (80- } \\
100 \%)\end{array}$ \\
\hline $\begin{array}{l}\text { SOCIAL SYSTEM } \\
\text { (change-impact) }\end{array}$ & $\begin{array}{l}\text { Reduction of fishers' income and } \\
\text { bankruptcies } \\
\text { New jobs found in the construction and } \\
\text { agriculture industries }\end{array}$ & $\begin{array}{l}\text { Total of } 3200 \text { jobs endangered. } \\
\text { Lower production (-21\%; FAO: } 2002- \\
07 / 2008-11 \text { ) } \\
2 \text { large hatcheries exporting oyster } \\
\text { seed are facing high larval mortality } \\
\text { rates }\end{array}$ & $\begin{array}{l}\text { Triploid spat from hatcheries. } \\
\text { Modified seasonal patterns of cultured } \\
\text { stocks. } \\
\text { Lower production (-30\%) } \\
\text { New costs from spillovers }\end{array}$ \\
\hline $\begin{array}{l}\text { GOVERNANCE SYSTEM } \\
\text { (change-impact) }\end{array}$ & $\begin{array}{l}\text { Weak governance: open access (1970s- } \\
\text { 1980s) } \\
\text { Co-management system since } 1990 \\
\text { Fishery closure } 1993-2006 \\
\text { The fishery re-opened in } 2008 \text { with a } \\
\text { precautionary approach }\end{array}$ & $\begin{array}{l}\text { Lack of governance to address acute- } \\
\text { onset change not driven by harvest } \\
\text { levels. } \\
\text { Creation of the Blue Ribbon Panel } \\
\text { (scientists + growers + managers): } \\
\text { action plan against ocean acidification } \\
\text { and how to adapt }\end{array}$ & $\begin{array}{l}\text { Lack of management measures to limit } \\
\text { spat over-buying and production } \\
\text { Restrictions on inter-basin transfers of } \\
\text { oysters } \\
\text { Technical measures on tables and } \\
\text { meshbags }\end{array}$ \\
\hline
\end{tabular}




\begin{tabular}{|c|c|c|c|}
\hline Table A & $\begin{array}{c}\text { Chesapeake Bay } \\
\text { Oysters (C. virginica) }\end{array}$ & $\begin{array}{l}\text { Matsushima Bay } \\
\text { Oysters (C. gigas) }\end{array}$ & $\begin{array}{l}\text { Bay of Quiberon } \\
\text { Oysters (C. Gigas) }\end{array}$ \\
\hline STRESSORS & $\begin{array}{l}\text { Presence of diseases (MSX and } \\
\text { Dermo) and predation (whelks and } \\
\text { rays) since } 2002 \text {. } \\
\text { Harvesting on the public grounds was low } \\
\text { to zero by the mid-1990s. }\end{array}$ & $\begin{array}{l}\text { An epidemic of Noro-virus food } \\
\text { poisoning after } 2011 \text { 's tsunami } \\
\text { because of destroyed sewage } \\
\text { facilities. }\end{array}$ & $\begin{array}{l}\text { Occasional hypoxia (more severe in } \\
2006 \text { ), near the bottom. Role of } \\
\text { eutrophication not clear. } \\
\text { Occasional toxic phytoplankton (Pseudo } \\
\text { Nitzschia) and OsHV1- } \mu \text { var since } 2008 \text {. }\end{array}$ \\
\hline $\begin{array}{l}\text { NATURAL SYSTEM } \\
\text { (change-impact) }\end{array}$ & $\begin{array}{l}\text { Parasites appeared in the early } 1960 \text { s } \\
\text { which are salinity dependent so that the } \\
\text { losses in oyster populations were greater } \\
\text { toward the mouth of the Chesapeake } \\
\text { Bay. Dead zones due to oxygen depletion } \\
\text { have also grown since that time. }\end{array}$ & $\begin{array}{l}\text { Lower productivity of oyster due to } \\
\text { unsold oyster occupation at the } \\
\text { farming system in the bay. In } 2011 \text {, } \\
\text { total seed oyster collection decreased } \\
\text { to } 40 \% \text { of } 2008 \text {. } \\
\text { Remain production less than } 20 \% \\
\text { level of the past average after } 2011 \text {. }\end{array}$ & $\begin{array}{l}\text { Changes in water quality (temperature, } \\
\text { Oxygen, Phytoplankton), in growth } \\
\text { rates and mortality risks. } \\
\text { The invasive Crepidula fornicate is } \\
\text { present at moderate densities. }\end{array}$ \\
\hline $\begin{array}{l}\text { SOCIAL SYSTEM } \\
\text { (change-impact) }\end{array}$ & $\begin{array}{l}\text { Population of } 30,942 \text { in the three } \\
\text { counties, with a } 36 \% \text { increase from } 1960 \\
\text { to } 2010 \text {. } \\
32 \text { small-scale fishers. }\end{array}$ & $\begin{array}{l}\text { Pop. 131,000 inhabitants. } 112 \text { oyster } \\
\text { farmers in } 2012 \text { (-10\% since } 2003 \text { and } \\
-7 \% \text { since 2011). 15,082 inhabitants } \\
\text { affected indirectly. } \\
\text { Reduced revenue affects } \\
\text { sustainability of oyster farming }\end{array}$ & $\begin{array}{l}60 \text { small-scale oyster farms (of less than } \\
10 \text { jobs each). } \\
\text { Decrease in the number of farms, } \\
\text { economic vulnerability. }\end{array}$ \\
\hline $\begin{array}{l}\text { GOVERNANCE SYSTEM } \\
\text { (change-impact) }\end{array}$ & $\begin{array}{l}\text { Virginia Oyster Heritage Program } \\
\text { initiated in 1999. Restoration of the } \\
\text { public grounds at the mouth of the } \\
\text { Rappahannock River by the } \\
\text { Commonwealth of Virginia in } 2000 \text { (shell } \\
\text { replenishment in public grounds). Partial } \\
\text { funding has come from federal agencies. }\end{array}$ & $\begin{array}{l}\text { Governor of Miyagi prefecture ask } \\
\text { Miyagi Fisheries Cooperative best } \\
\text { proper management of coastal water. } \\
\text { Miyagi Fisheries Cooperative is } \\
\text { responsible to manage coastal water } \\
\text { production. In 2007, } 31 \text { independent } \\
\text { Cooperatives have consolidated for } \\
\text { cost-cutting purposes. }\end{array}$ & $\begin{array}{l}\text { State intervention, industry } \\
\text { representatives at the national (CNC) } \\
\text { and local (CRC) levels. } \\
\text { Scientific support by lfremer. } \\
\text { No particular change, except the access } \\
\text { to public grounds. }\end{array}$ \\
\hline
\end{tabular}




\begin{tabular}{|c|c|c|c|}
\hline Table B & Uruguayan Yellow clam (Mesodesma mactroides) & US North Pacific Oysters (C gigas) & Bay of Bourgneuf oysters (C. Gigas) \\
\hline ADAPTIVE CAPACITY & $\begin{array}{l}\text { Job opportunities in other sectors } \\
\text { No financial aid to fishers. } \\
\text { Important research activity on YC fishery for a long } \\
\text { time. } \\
\text { Co-management in force since } 1990\end{array}$ & $\begin{array}{l}\text { Strong relationships between the } \\
\text { industry, researchers, NGOs for solutions. } \\
\text { Funds available to do the basic science. } \\
\text { High levels of human resources in } \\
\text { communities to address problem. }\end{array}$ & $\begin{array}{l}\text { National funds to support affected } \\
\text { farms ( } 20 \mathrm{M} € . \mathrm{yr}^{-1} \text { at the national } \\
\text { level) } \\
\text { Public research (causes and new } \\
\text { virus-resistant species) } \\
\text { No private insurance against disease } \\
\text { No alternative virus-resistant oyster } \\
\text { species }\end{array}$ \\
\hline RESPONSES & $\begin{array}{l}\text { Fishery closure } 1993-2007 \text {; } \\
\text { The fishery was re-opened under a co-management } \\
\text { system in } 2008 / 2009 \text {. } \\
\text { a) monthly TAC; } \\
\text { b) restricted nb of licenses ( } 40) \text {; } \\
\text { c) individual quotas; } \\
\text { d) minimum clam size; } \\
\text { e) only hand-gathering allowed } \\
\text { f) spatial management } \\
\text { g) harvesting season (summer) }\end{array}$ & $\begin{array}{l}\text { Creation of plan for hatcheries to draw } \\
\text { water in at specific times indicated by a } \\
\text { warning system. } \\
\text { Transfer of hatchery production to } \\
\text { unaffected waters in Hawaii. } \\
\text { Long-term research, monitoring plan } \\
\text { through Blue Ribbon Panel. Genetic } \\
\text { studies under way to identify resilient } \\
\text { broodstock strain(s). }\end{array}$ & $\begin{array}{l}\text { Restrictions on inter-basin transfers } \\
\text { at the national level } \\
\text { No new management measure } \\
\text { implemented at the bay-level } \\
\text { Individual responses: increasing } \\
\text { number of spat collectors and } \\
\text { hatchery seeds } \\
\text { Offshore tech. experiments }\end{array}$ \\
\hline APPRAISAL & $\begin{array}{l}\text { The ecosystem is gradually recovering from } \\
\text { overfishing and MMB, but not in line with pre-mass } \\
\text { mortality levels, maintaining part-time jobs for fishers } \\
\text { and less attractiveness for young people. }\end{array}$ & $\begin{array}{l}\text { Short-term success: hatcheries still open, } \\
\text { harvests \& jobs preserved. } \\
\text { Long-term outcomes still pending. }\end{array}$ & $\begin{array}{l}5 \text { years after, high survival rate of } \\
\text { farms despite the high larval } \\
\text { mortality rates } \\
\text { The causes of OsHV-1-mVar } \\
\text { emergence since } 2008 \text { onwards still } \\
\text { unknown }\end{array}$ \\
\hline
\end{tabular}




\begin{tabular}{|c|c|c|c|}
\hline Table B & $\begin{array}{l}\text { Chesapeake Bay } \\
\text { Oysters (C. virginica) }\end{array}$ & $\begin{array}{l}\text { Matsushima Bay } \\
\text { Oysters (C. gigas) }\end{array}$ & $\begin{array}{l}\text { Bay of Quiberon } \\
\text { Oysters (C. Gigas) }\end{array}$ \\
\hline ADAPTIVE CAPACITY & $\begin{array}{l}\text { Very vulnerable to changes in fresh water } \\
\text { flow from storms, pollution levels, } \\
\text { sedimentation which reduces population } \\
\text { by about } 50 \% \text { per year. } \\
\text { Since the decline in the } 1960 \text { s, alternative } \\
\text { sources of income (other species) for } \\
\text { fishers. }\end{array}$ & $\begin{array}{l}\text { Changes of the bay environment } \\
\text { caused by sudden Tsunami. } \\
\text { Sanitary inspection system in every } \\
\text { prefecture under government } \\
\text { subsidies. Complete sterilization of } \\
\text { the virus at the infestation site by } \\
\text { public sanitary expert. }\end{array}$ & $\begin{array}{l}\text { Scientific support (Ifremer) with a good } \\
\text { monitoring system of water and oyster } \\
\text { quality. } \\
\text { Government support with intervention } \\
\text { schemes (Agriculture Calamity scheme) }\end{array}$ \\
\hline RESPONSES & $\begin{array}{l}\text { A large scale restoration program was } \\
\text { initiated in 2000: artificial reefs built in } \\
2001+\text { intensive shelling (total cost of } \\
\$ 2.4 \mathrm{M} \text { ). } \\
\text { The state established oyster harvest } \\
\text { rotational grounds opening (season time } \\
\text { and length, daily limit, cull size set } \\
\text { annually). Gear limitation (only hand } \\
\text { scrapes). } \\
\text { Creation of brood stock sanctuaries (no- } \\
\text { take zones) }\end{array}$ & $\begin{array}{l}\text { Financial support from local } \\
\text { government to compensate } \\
\text { insurances of Cooperatives. } \\
\text { New laws on food safety. } \\
\text { Shucked oysters by heat treatment } \\
\text { over } 85^{\circ} \mathrm{C} \text { (Noro-virus is inactivated) } \\
\text { but prices and incomes halved. } \\
\text { Test application of various natural } \\
\text { chemicals to inactivate Norovirus. } \\
\text { Construction of sewage treatment } \\
\text { facilities. }\end{array}$ & $\begin{array}{l}\text { Government subsidies + tax alleviation } \\
\text { Reduction in the number of farms (from } \\
80 \text { in the early } 2000 \text { s to } 10 \text { in } 2010 \text { ). }\end{array}$ \\
\hline APPRAISAL & $\begin{array}{l}\text { Increased oyster population on shelled } \\
\text { grounds. For entire state largest oyster } \\
\text { harvest in } 26 \text { years in 2012-13. } \\
\text { Increase number of violations of } \\
\text { regulations including oystering at night, } \\
\text { harvesting without a license, gathering } \\
\text { undersized oysters. }\end{array}$ & $\begin{array}{l}\text { Effective means for virus inactivation } \\
\text { or useful technology to culture the } \\
\text { virus have not been established yet. }\end{array}$ & $\begin{array}{l}\text { Production of } 15,000 \text { t before } 2006 \text {, } \\
\text { half that level after. }\end{array}$ \\
\hline
\end{tabular}


TABLE C - List of criteria used in the multidimensional resilience analysis.

\begin{tabular}{|c|c|}
\hline $\begin{array}{l}\text { R-dimensions / definitions / } \\
\text { references }\end{array}$ & Criteria (I-ADApT questionnaire, literature) \\
\hline $\begin{array}{l}\text { H-Resilience (Holling } 1973- \\
\text { static resilience of the natural } \\
\text { system). The H-Resilience } \\
\text { determines the persistence of } \\
\text { relationships within a system } \\
\text { and measures the ability of } \\
\text { this system to absorb } \\
\text { changes of state variables, } \\
\text { driving variables, and } \\
\text { parameters and still persists. }\end{array}$ & $\begin{array}{l}\text { Q6. Prior to the main issue, what is the ecological status and habitat of the } \\
\text { ecosystem at the ecosystem level ( } \mathbf{L} \text { if severely degraded; } \mathbf{M} \text { moderately; } \mathbf{H} \text { if } \\
\text { not degraded)? } \\
\text { Q7. What was the productivity of the system prior to the main issue (Low, } \\
\text { Medium or High)? } \rightarrow \mathbf{H} \text { if high productivity; } \mathbf{M} \text { if moderate; } \mathbf{L} \text { if low) (Palumbi } \\
\text { et al. 2008). } \\
\text { Stability of the natural system ( } \neq \text { resilience) = variability around a state } \\
\text { equilibrium. A system can be unstable but resilient (e.g. highly fluctuating } \\
\text { climate conditions) and the other way around (in temperate systems not } \\
\text { prepared to cope with climate shocks). } \rightarrow \boldsymbol{H} \text { if high fluctuations; } \boldsymbol{M} \text { if } \\
\text { moderate; } \boldsymbol{L} \text { if stable) (Holling } 1973 \text { ). } \\
\text { Probability of sustainable biomass ( } \boldsymbol{H} \text { if the biomass level is close to } M S Y ; \boldsymbol{M} \text { if } \\
\text { slightly beyond } M S Y ; \boldsymbol{L} \text { if far beyond } M S Y \text { ). } \\
\text { Same abundance and number of species, number of trophic levels and } \\
\text { interspecific interactions ( } \boldsymbol{H} \text { if true, } \boldsymbol{M} \text { if partially true, } \boldsymbol{L} \text { if false). }\end{array}$ \\
\hline $\begin{array}{l}\text { P-Resilience (Pimm } 1984- \\
\text { "how fast the variables return } \\
\text { towards their equilibrium } \\
\text { following a perturbation" }\end{array}$ & 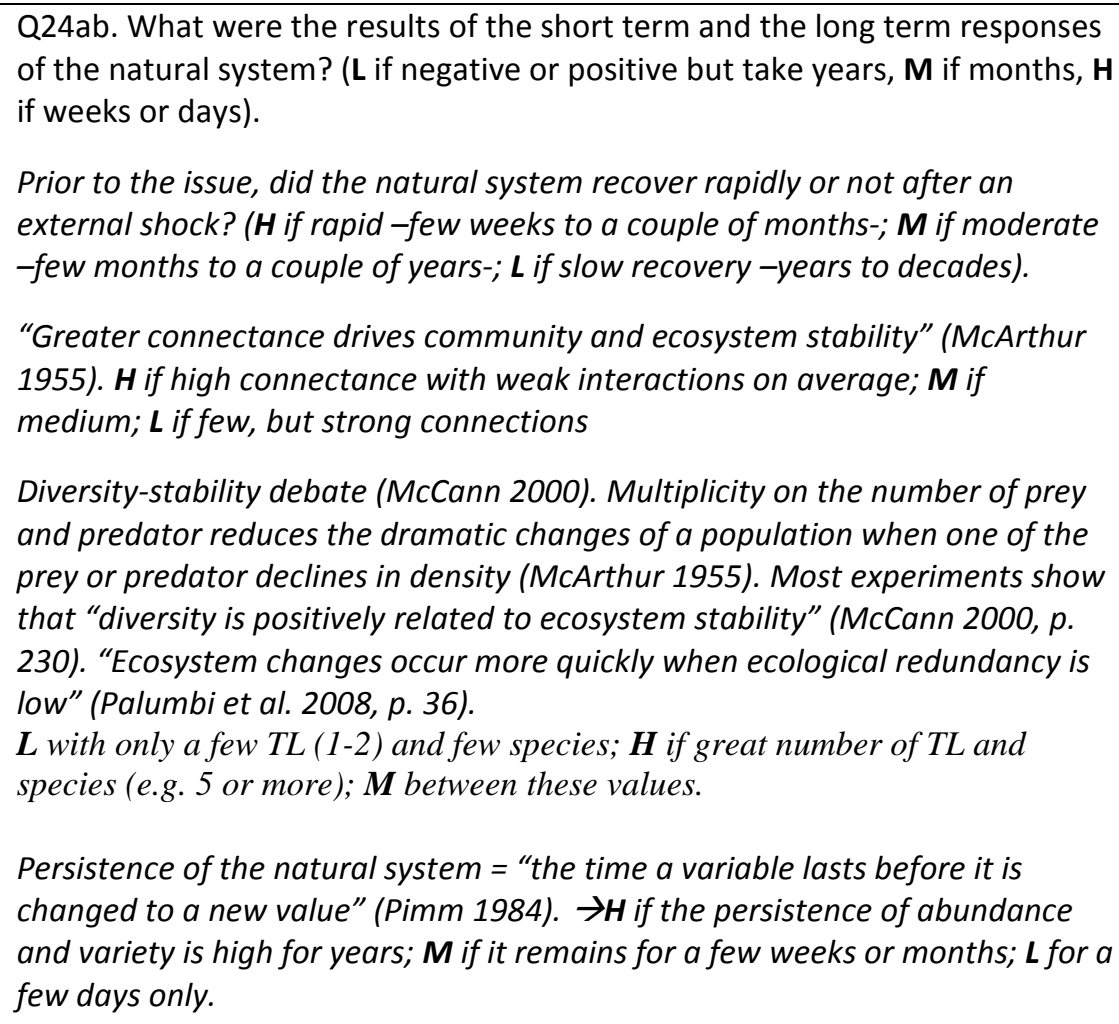 \\
\hline $\begin{array}{l}\text { S-Resilience (Social and } \\
\text { economic static resilience): } \\
\text { ability of an economy to } \\
\text { minimize welfare losses after }\end{array}$ & $\begin{array}{l}\text { BI. Number of people affected by the Main Issue expressed as a ratio to the } \\
\text { total number of people }(\mathbf{H}<10 \% ; 10 \leq \mathbf{M}<20 \% ; \mathbf{L} \geq 20) \text {. } \\
\text { Q8. How many activities were impacted by the main issue? ( } \mathrm{L} \text { if more than }\end{array}$ \\
\hline
\end{tabular}




\begin{tabular}{|c|c|}
\hline $\begin{array}{l}\text { Economic resilience indices } \\
\text { developed by Cutter et al. } \\
\text { 2010; Bruneau et al. 2003; } \\
\text { Jordan et al. 2011; Mayunga } \\
\text { et al. 2007; Fisher et al. 2010; } \\
\text { Norris } 2011 \text {; Burton 2012; } \\
\text { Rose } 2009 \text { (Rose and } \\
\text { Krausman 2013, p. } 79 \text { ). }\end{array}$ & 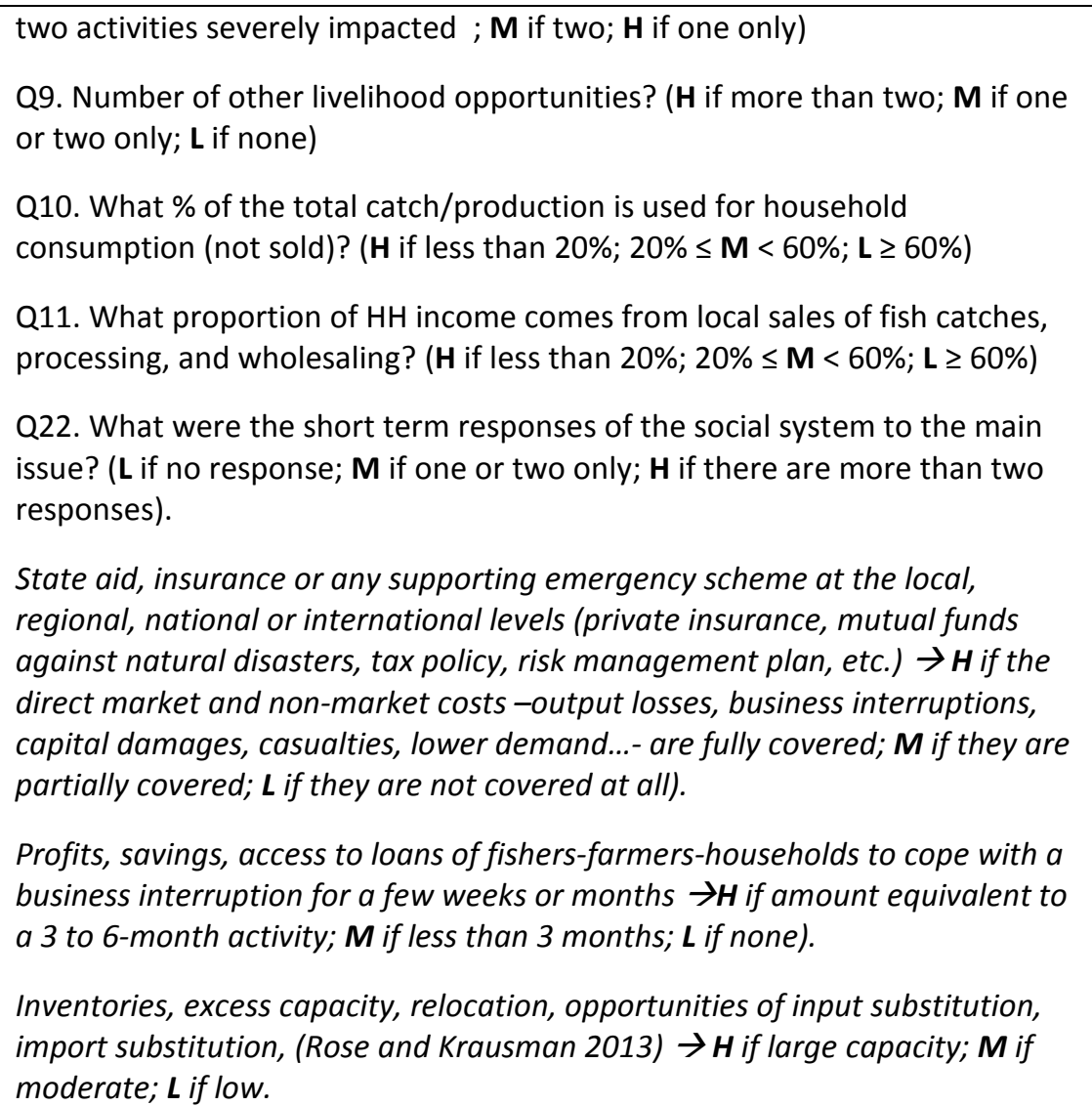 \\
\hline $\begin{array}{l}\text { D-resilience ("ability to } \\
\text { reconstruct and recover } \\
\text { quickly", capacity to innovate, } \\
\text { to diversify...); "capacity of } \\
\text { innovation and use of } \\
\text { disturbances as opportunity" } \\
\text { (Berkes et al. 2003; Hughes et } \\
\text { al. 2005; Hertzler and Harris } \\
\text { 2010) }\end{array}$ & $\begin{array}{l}\text { (Q11). Change of } \mathbf{H H} \% \text { income coming from local sales of fish catches, } \\
\text { processing, and wholesaling? ( } \mathbf{H} \text { if the rate is lower or equal to }-5 \% ; \mathbf{M} \text { if the } \\
\text { rate is negative and greater than -5\%; } \mathbf{L} \text { if no change) } \\
\text { Q22. What were the long term responses of the social system to the main } \\
\text { issue? ( } \mathbf{L} \text { if no response; } \mathbf{M} \text { if one or two); } \mathbf{H} \text { if three or more responses). } \\
\text { Degree of diversification. Capacity of fishers/farmers to turn to other marine } \\
\text { productions or to alternative jobs. ( } \boldsymbol{H} \text { if more than two alternatives; } \boldsymbol{M} \text { if one } \\
\text { or two alternatives and } \mathbf{L} \text { if none). } \\
\text { Ability of fishers/farmers to innovate (proved in the past); } \rightarrow \boldsymbol{H}=\text { strong } \\
\text { innovating capacity; } \boldsymbol{M}=\text { moderate; } \boldsymbol{L}=\text { poor } \\
\text { Turnover of marine products over time-seasonally, from year to year...- (vs } \\
\text { stability) } \rightarrow \boldsymbol{H} \text { if frequent turnover; } \boldsymbol{M} \text { if moderate; } \boldsymbol{L} \text { if stable and limited scope } \\
\text { of goods. }\end{array}$ \\
\hline $\begin{array}{l}\text { STG-Resilience (Short-term } \\
\text { governance: Collective } \\
\text { capacity to cope with } \\
\text { disturbances with existing } \\
\text { institutions) (Hughes et al. } \\
\text { 2005; Charles 2007; Kajitani } \\
\text { and Tatano 2009). }\end{array}$ & $\begin{array}{l}\text { Q15. What are the key rules, regulations, instruments and measures } \\
\text { employed to achieve the management objectives? ( } \mathbf{L} \text { if none, } \mathbf{M} \text { if input or } \\
\text { output measures alone, } \mathbf{H} \text { if both input and output measures or formal co- } \\
\text { management) } \\
\text { Q16. Are there any informal rules, regulations, instruments and measures } \\
\text { that play an important role in the governance of fisheries and aquaculture? ( } \mathbf{} \\
\text { if none, } \mathbf{M} \text { if one or two, } \mathbf{H} \text { if more than two). } \\
\text { Q19. How concentrated is social power in the area? (on a 5-point scale: } \mathbf{L} \text { if }\end{array}$ \\
\hline
\end{tabular}




\begin{tabular}{|l|l|}
\hline & $\begin{array}{l}\text { dispersion; } \mathbf{M} \text { if moderately concentrated; } \mathbf{H} \text { if concentrated) } \\
\text { Q22. What were the short term responses of the governing system to the } \\
\text { main issue? (L if no response; } \mathbf{M} \text { if limited; } \mathbf{H} \text { if variety of responses). }\end{array}$ \\
\hline $\begin{array}{l}\text { LTG-Resilience (Long-term } \\
\text { governance: ability to reform } \\
\text { existing institutions and } \\
\text { strengthen the adaptive } \\
\text { capacity of the system in the } \\
\text { LR); "supporting flexible } \\
\text { institutions and social } \\
\text { networks in multi-level } \\
\text { governance systems" (Hughes } \\
\text { et al. 2005). }\end{array}$ & $\begin{array}{l}\text { Q17. Nature of the relationship between occupations (conflict / cooperation } \\
\text { on a 5-point scale)? (L if conflict; } \mathbf{H} \text { if cooperation; } \mathbf{M} \text { in-between) } \\
\text { Q18. Who dominates or wields the most social power in the area? ( } \mathbf{L} \text { if very } \\
\text { decentralized -fishers associations). } \\
\text { Q20. Were there any structural changes in the governing system or } \\
\text { individuals prior to the main issue? (H if large, } \mathbf{M} \text { if some, L if no change). } \\
\text { Q21. Were there any changes to the key rules, regulations, instruments and } \\
\text { measures, or have any new ones been introduced prior to the main issue? (L } \\
\text { if no change; } \mathbf{M} \text { for several new rules; } \mathbf{H} \text { of many new rules). } \\
\text { Q22. What were the long term responses of the governing system to the } \\
\text { main issue? (L if no response, } \mathbf{M} \text { if limited, } \mathbf{H} \text { of variety of responses). } \\
\text { Research-development capacity (number of researchers, facilities, national or } \\
\text { regional funding schemes, quality of research measured by the number of } \\
\text { publications on the issue, creation of panels, clusters,...) to cope with the issue } \\
\text { (H for high capacity, } \boldsymbol{M} \text { for medium and } \mathbf{L} \text { for low capacity). } \\
\text { Degree of compliance and acceptation of new rules and institutions ( } \boldsymbol{H} \text { for } \\
\text { strong degree of compliance, } \boldsymbol{M} \text { for moderately organized or } \boldsymbol{L} \text { for } \\
\text { individualism and non-organized behaviors). }\end{array}$ \\
\hline
\end{tabular}

Legend:

$\mathrm{BI}=$ Background information in the I-ADApT questionnaire. All criteria with a Q(question) number are taken from the I-ADApT questionnaire (http://www.imber.info/Science/Working-Groups/HumanDimensions/I-MBER-ADApT).

The variety and nature of answers given by experts in the I-ADApT framework and sometimes found in the literature are far richer (included in italic in the table). These answers can therefore be used to extend the list of criteria (e.g. research-development capacity related to the main issue, government financial support for the fishing/aquaculture industry, etc.). 
TABLE D - Monte Carlo analysis of Multidimensional Resilience Index

(500 random trials - uniform distribution law)

\begin{tabular}{lllllll} 
& MB & PS & BB & CB & BdC & BQ \\
Mean & 0.40 & 0.33 & 0.31 & 0.29 & 0.18 & 0.05 \\
\hline St. Dev. & 0.07 & 0.08 & 0.06 & 0.06 & 0.04 & 0.02 \\
Mean St. Error & 0.00 & 0.00 & 0.00 & 0.00 & 0.00 & 0.00 \\
\hline Minimum & 0.23 & 0.14 & 0.17 & 0.13 & 0.08 & 0.00 \\
\hline First Quartile & 0.35 & 0.27 & 0.26 & 0.25 & 0.15 & 0.04 \\
\hline Median & $\mathbf{0 . 4 0}$ & $\mathbf{0 . 3 2}$ & $\mathbf{0 . 3 0}$ & $\mathbf{0 . 2 9}$ & $\mathbf{0 . 1 8}$ & $\mathbf{0 . 0 5}$ \\
\hline Third Quartile & 0.45 & 0.38 & 0.34 & 0.33 & 0.21 & 0.07 \\
\hline Maximum & 0.57 & 0.56 & 0.46 & 0.44 & 0.31 & 0.10 \\
\hline Skewness & 0.08 & 0.17 & 0.24 & 0.08 & 0.19 & -0.06 \\
\hline Kurtosis & -0.65 & -0.22 & -0.33 & -0.16 & -0.41 & -0.63
\end{tabular}

Legend: $\mathrm{MB}=$ Matsushima Bay, $\mathrm{PS}=$ Puget Sound, $\mathrm{BB}=$ Bay of Bourgneuf), $\mathrm{CB}=$ Chesapeake Bay, $\mathrm{BdC}=$ Barra del Chuy, $\mathrm{BQ}=$ Bay of Quiberon.

Interpretation: Skewness identifies how symmetrical the distribution is; a long tail to the right (left) has a positive (negative) skew. Kurtosis identifies how Gaussian the distribution is: a flatter (more peaked) distribution has a negative (positive) value. 